\title{
Alluvial fans on volcanic islands: A morphometric perspective (Sao Vicente, Cape Verde)
}

Stokes, M::0000-0003-3788-4615

http://hdl.handle.net/10026.1/16132

10.1016/j.geomorph.2020.107356

Geomorphology

Elsevier BV

All content in PEARL is protected by copyright law. Author manuscripts are made available in accordance with publisher policies. Please cite only the published version using the details provided on the item record or document. In the absence of an open licence (e.g. Creative Commons), permissions for further reuse of content should be sought from the publisher or author. 


\section{Journal Pre-proof}

Alluvial fans on volcanic islands: A morphometric perspective (São Vicente, Cape Verde)

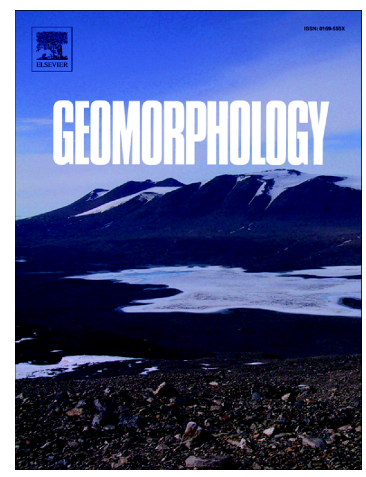

Martin Stokes, Alberto Gomes

PII:

S0169-555X(20)30329-9

DOI: https://doi.org/10.1016/j.geomorph.2020.107356

Reference:

GEOMOR 107356

To appear in:

Geomorphology

Received date:

22 May 2020

Revised date:

17 July 2020

Accepted date:

17 July 2020

Please cite this article as: M. Stokes and A. Gomes, Alluvial fans on volcanic islands: A morphometric perspective (São Vicente, Cape Verde), Geomorphology (2020), https://doi.org/10.1016/j.geomorph.2020.107356

This is a PDF file of an article that has undergone enhancements after acceptance, such as the addition of a cover page and metadata, and formatting for readability, but it is not yet the definitive version of record. This version will undergo additional copyediting, typesetting and review before it is published in its final form, but we are providing this version to give early visibility of the article. Please note that, during the production process, errors may be discovered which could affect the content, and all legal disclaimers that apply to the journal pertain.

(C) 2020 Published by Elsevier. 


\title{
Alluvial fans on volcanic islands: a
}

\section{morphometric perspective (São}

\section{Vicente, Cape Verde)}

\author{
Martin Stokes*, Alberto Gomes
}

School of Geography, Earth and Environmental Sciences, University of Plymouth, Devon, PL4 8AA, United Kingdom

Department of Geography, University of Porto, Via Panorâmica s/n, 4159-564 Porto, Portugal

*m.stokes@plymouth.ac.uk

\section{Highlights}

- Investigation of alluvial fan distribution and morphology on a volcanic island

- DEM measurement of fan and catchment morphometric properties (area, gradient etc.)

- Regression residuals reveals dominance of small-steep and large-low gradient fans 
- Fans distributed according to volcano structure, with building space a key control

- Climate and base-level changes modify fan morphometric properties

\section{Abstract}

The distribution, morphology and development of volcanic island alluvial fans are investigated using São Vicente from the Cape Verde volcanic chain (east-central Atlantic Ocean). This is a tectonically and volcanically inactive dryland setting, comprising an eroded Plio-Pleistocene composite volcano overlying a submarine shield volcano. We mapped 228 alluvial fans, quantifying fan (F) and catchment (C) morphological properties (area $[A]$, gradient $[G]$, relief $[R]$, length $[L])$. Fans and catchments of varying size and gradient are distributed around the island coastal margins (6\%) and along interior valley sides (94\%). Regression results (i.e. +ve / -ve slopes of best fit lines) conformed to broader fan research but with weak correlations, and coefficient-exponent values outside, or at the lower end of values reported from non-volcanic settings. Analysis of fan area and gradient vs catchment area regression residuals revealed fans were dominated by small-steep gradient (28\%) and large-low gradient forms (39\%). Fan building space is a fundamental control, specifically linked to volcano structure, but with interplay between rock strength, base level, and climate. Fans around the volcanic edifice flanks are uncommon due to steep flank slopes. Where flank margin fans occur they are typically small and steep forms due to marine erosion. Fans along flank incised valleys are common. Large low gradient fans are associated with a major volcanic rift-aligned valley structure, with extensive erosion into altered and weathered 
edifice-core lithologies. Small-steep gradient fans are associated with edifice flank valleys. Steeper and narrower valley forms reflect incision into stronger lithologies of the composite volcano flanks, restricting fan building space. Fans located within the volcano central depression are amongst the largest and lowest gradient types, building into the eroded and unconfined edifice core space. Coalescence, apex-toe incision, toe erosion and catchment stream channel backfilling displayed by most fans suggest landscape erosion dominates during more arid periods (e.g. interglacials), with the dryland setting generating limited sediment and insufficient flood runoff for transport and fan deposition. Fan building likely occurs during wetter periods linked to Quaternary climate variability. Quaternary eustatic variations are relevant for the volcano edifice margins where sea level changes control fan building space and erosion.

\section{Keywords}

Alluvial fans, morphometrics, volcanic geomorphology, volcanic island, Cape Verde

\section{Introduction}

Alluvial fans are conical shaped bodies of alluvial sediment whose width and length dimensions vary from tens of metres to tens of kilometres (Mather et al., 2017, Bowman, 2019). They develop where a laterally confined stream emerges into a more unconfined area, typically at mountain fronts, along valley sides or at tributary junctions within upland or mountain landscapes (Harvey, 2011). The hydrological and sedimentary processes that build alluvial fans reflect interplay between the 
regional tectonic and climatic setting of the fluvial system in which the fan is developing but also the local geological and geomorphological characteristics of the fan catchment and its depositional setting (Harvey et al., 2005; Blair and McPherson, 2009; Harvey, 2011; Bowman, 2019). Investigations of these controlling factors have commonly utilised quantitative morphometric approaches, notably regression analysis of fan (e.g. area, gradient) and catchment (e.g. area, gradient, relief) variables (Bull, 1977; Harvey, 2011). Studies often highlight catchment geology (Hooke and Rohrer, 1977), base level (Mather, et al., 2000; Harvey, 2002a), mountain front and depositional setting tectonic characteristics (Silva et al., 1992; Viseras et al., 2003; Bahrami, 2013) and depositional area confinement (Stokes and Mather, 2015) as major controls on fan development and their morphometric properties.

Morphometric research on alluvial fans is dominated by examples from tectonically active dryland mountain settings (e.g. Western USA, SE Spain etc, Harvey, 2002a, Blair and McPherson, 2009). However, a notable research gap exists concerning alluvial fans within volcanic landscapes. Such landscapes and their volcano edifices occur across a wide range of tectonic and crustal settings, to include collisional, intraplate, and rifting areas underlain by continental crust, through to volcanic islands associated with oceanic crust (Thouret, 1999). Volcanic topography is created by material erupted through a vent or fissure from an underlying magmatic system to produce a 'volcano'-shaped edifice (de Silva and Lindsay, 2015). Morphology relates to magma composition, where low-angle $\left(<10^{\circ}\right)$ shield volcanoes are produced by mafic lavas and steep-sided $\left(<30^{\circ}\right)$ composite volcanoes are produced by more intermediate-silicic lavas (de Silva and Lindsay, 2015). Alluvial fan formation on a volcanic edifice would require the development of a drainage network into the edifice 
flanks (e.g. Menéndez et al., 2008) to facilitate locations for catchment and depositional area development. Fans could build around the edifice base as 'mountain front' fans or within a flank drainage network along valley sides or at tributary junction locations. Inactive periods of volcanic activity are likely to favour fan development, allowing dominance of climate-related weathering, erosion, and sediment transport to occur. In morphometric terms, catchment properties are likely to reflect the volcano structure and rock types in terms of volcanic alteration and broader climate-related weathering; fan building processes should reflect the relative uniformity of volcanic rock type, depending on alteration / weathering, informing on fan area and gradient properties; and finally the space for fan building should be restrictive due to steep volcano flanks and narrow, deeply incised flank margin valleys meaning fan size may be limited or prone to change due to erosion.

In this study we provide a first investigation into alluvial fan morphometric properties associated with a volcanic island landscape using São Vicente from the Cape Verde archipelago of the east-central Atlantic Ocean (Fig. 1). Here, alluvial fans are abundant landforms, occurring in different volcanic edifice contexts around the island margin and interior. The island comprises a Miocene submarine shield volcano overlain by a Plio-Pleistocene subaerial composite volcano (Anchochea et al., 2010), collectively constructed onto Jurassic-Cretaceous oceanic crust of the stationary African-Nubian plate (Pollitz, 1991). The volcanic edifice comprises dipping basaltic lava flows, cross cutting intrusive dyke swarms and remnants of major flank collapses (Anchochea et al., 2010). The coastline provides a base level for edifice flank streams and edifice interior valleys. Tectonic uplift of the island is negligible (Ramalho et al., 2010), and thus eustatic base-level is likely more significant for controlling longer term fan development. The regional climate is arid and the island 
lacks vegetation cover (Durate and Romeiras, 2009); thus, alluvial fans on São Vicente are functioning within a dryland setting characterised by low frequency but high magnitude rainfall and runoff events conducive for alluvial fan activity (e.g. Field, 2001; Harvey, 2011).

This study aims to describe the distribution and morphometric properties of alluvial fans on São Vicente volcanic island, and to consider the key factors that influence them. To achieve these, the spatial distribution of alluvial fans is established in relation to different volcanic island geological and morphological contexts. Each fan system, comprising a catchment and its downstream fan, is morphologically quantified (i.e. area, gradient, relief etc). Examples of these fans are illustrated using remote sensing and field observations. The fan database is analysed using statistical approaches. This includes regression analysis and exploration of regression residuals to identify groups of fans with specific fan area and gradient configurations. The morphometric relationships and residual groupings are then discussed in relation to volcano structure, geology, and edifice morphology, alongside fan history controls of base-level and climate change contexts.

\section{Geological and geomorphological background}

\subsection{Cape Verde}

São Vicente is part of the Cape Verde archipelago (Fig. 1), a chain of low latitude Atlantic Ocean volcanic islands positioned between $14-17^{\circ} \mathrm{N}$ of the Equator, some 570-800 km offshore west Africa (Duarte and Romeiras, 2008). The islands are 
variably preserved volcanic edifices developed on the Cape Verde Rise, an up domed and fractured intraplate sea floor region (Williams et al., 1990). Here, the African-Nubian Plate is stationary, with mega swell formation and volcanic eruptions linked to mantle plume hot spot activity impinging on the underside of old (JurassicCretaceous) thickened ( 22 km) oceanic crust (Pollitz, 1991; Holm., et al 2008; Pim et al., 2008; Vinnik et al., 2011). Building of Cape Verde commenced in the early Miocene by oceanic crust sill emplacement, followed by extended periods of volcanic activity and island formation from $16 \mathrm{Ma}$ to the present (Plesner et al., 2002). This construction follows a series of volcanic stages (1: shield volcano, 2 : composite volcano, 3: erosion, and 4: volcanic rejuvenation) typical of a plate moving over a mantle hotspot, as recorded on other Atlantic Ocean volcanic island chains (Paris et al., 2005). Plume-related eruptive lavas (basanites-tephrites and nephelinites) are the commonest volcanic product, with minor occurrences of mantle sourced carbonatite intrusions (Holm, et al., 2008).

The sea floor fracture configuration and variably aged volcanism of the shieldcomposite-erosion-rejuvenation stages has built islands of differing morphologies (Mitchell, 1999; Duarte and Romeiras, 2009). These range from high relief forms (>1500 m) with a well-preserved composite volcanic edifice form (e.g. Fogo) through to lower relief forms $(<500 \mathrm{~m})$ that are highly eroded and lacking a classical volcanic edifice shape (e.g. Sal). São Vicente represents an intermediate form, comprising a relatively lower relief landscape ( 725 $\mathrm{m}$ ) where the composite volcanic edifice has been partly eroded but is still visible and possible to reconstruct. Alluvial fans are found on most Cape Verde islands but the intermediate forms with reliefs of $\sim 700$ $1300 \mathrm{~m}$ appear to be the most conducive for widespread alluvial fan development. 


\subsection{São Vicente}

São Vicente is a $24 \times 16 \mathrm{~km}$ rhomb-shaped island with an area of $224 \mathrm{~km}^{2}$.

Geomorphologically, it comprises a central lowland region (relict volcanic centre) bordered by a discontinuous concentric mountain range (relict volcanic edifice), with peak elevations varying between $\sim 450-750 \mathrm{~m}$ (Fig. 2A). The range is breached in the SW and E by major wide valleys (respectively, Ribeira de São Pedro / Calhau) and opens to the NNW into Mindelo Bay. Numerous minor narrow valleys with NW-SE through to NE-SW orientations radiate away from the concentric mountain range to the coast. Ridges separating the valleys dip seawards and represent the eroded remnants of the volcanic edifice surface. Valleys contain dry ephemeral streams, comprising bedrock or thin $(<5 \mathrm{~m})$ alluvial fill. Slopes $\left(10^{\circ}\right.$ mean) vary from near vertical cliffs $\left(30-80^{\circ}\right)$ in the highest elevations, to moderate $\left(10-30^{\circ}\right)$ and lower slope $\left(<10^{\circ}\right)$ forms at mid-low elevation settings (Fig. 2B). Bedrock weathering, erosion and fluvial hydrology is governed by an arid climate typical of the African Sahel resulting in a sparsely vegetated landscape (Duarte and Romeiras, 2009). Climate is affected by interplay between the Azores anticyclone, the Intertropical Convergence Zone (ITCZ), and mid-Atlantic air mass movements induced by their seasonal changes of location resulting in low rainfall (113 $\mathrm{mm}$ average), warm temperatures $\left(23^{\circ} \mathrm{C}\right.$ average; $27^{\circ} \mathrm{C}$ max) and strong, Saharan dust-laden winds (NE trades and Harmattan) (Duarte and Romeiras, 2009; Read, 2010).

Alluvial fan catchments are developed into volcanic bedrock (Fig. 3; Table 1) comprising three units typical of hot spot volcano evolution (Paris et al., 2005; Anchochea et al., 2010): 1) a Miocene submarine edifice (Basal Complex), 2) a Plio- 
Pleistocene subaerial edifice (São Vicente Edifice) and 3) Pleistocene volcanics (Recent Volcanics). The Miocene Basal Complex forms the undulating lowland area bordering Mindelo town (Fig. 4). It is highly altered / weathered, comprising basic lavas and dike swarms with minor occurrences of plutonic gabbro (Ancochea et al., 2010). The overlying São Vicente edifice dominates the island geology and overall morphology (Fig. 3; Table 1). It represents the eroded remnants of a single composite volcano comprising a thick seaward dipping layered lava pile sequence (Ancochea et al., 2010). It comprises three construction phases: 1) Lower São Vicente edifice (LSVE), 2) Praia Grande flank collapse (PGFC) and 3) the Upper São Vicente edifice (USVE) (Fig. 3; Table 1). The LSVE is characterised by an initial 400 $\mathrm{m}$ thick basaltic construction phase of pahoehoe flows (Mindelo Formation), followed by $600-700 \mathrm{~m}$ of aa lavas (Madeiral-Monte Cara Fm: MMC) dipping at up to $12^{\circ}$ seaward (Fig. 4B-D). The LSVE is crosscut by sub-horizontal to subvertical, NW-SE through to NE-SW oriented dikes with a radial pattern indicating a central island source (Fig. 3A). The USVE is restricted to NE São Vicente where basaltic lavas of the Monte Verde Formation (MV) have developed into the backscar of the PGFC (Figs. 3B and 4E). Upwards projection of dipping LSVE lavas (Fig. 3B) suggests an estimated volcano edifice summit elevation of $2600 \mathrm{~m}$ (Ancochea et al., 2010), highlighting the highly eroded modern relief configuration (peaks of $<750 \mathrm{~m}$ ).

Recent Volcanics (RV) are restricted to the NE and SE of the island (Figs. 3 and 4F) characterised by strombolian cones and lava flows. São Vicente also possesses Pleistocene sediments, comprising aeolian dunes, marine terrace and shore platforms and alluvial sediments (fan and valley fill). Aeolian dunes (Aeo.) are most common along the Praia Grande coast, interbedding with and eroded by alluvial 
sediments (Fig. 4E). The Praia Grande and São Pedro coasts possess Late

Pleistocene (?) shore platforms and related marine terrace deposits (Fig. 4D) at 2-4 m, $12 \mathrm{~m}$ and $\sim 18 \mathrm{~m}$ above sea level (Ramhalo et al., 2010; Ramhalo, 2011). These marine levels are often buried by alluvial fan sediments suggesting a Pleistocene climate-eustatic fan development relationship.

\section{Methods}

Alluvial fans were examined using remote sensing, field, and statistical morphometric approaches. Google Earth satellite imagery was used to locate fans and to map out fan margins. These data were imported into GIS (ArcMap 10.6), where they were combined with a $12 \mathrm{~m}$ resolution Tan-DEM-X Digital Elevation Model (DEM) (DLR, 2016). An island drainage network was extracted from the DEM using ARC GIS hydrotools to be used alongside the DEM and ESRI base map satellite data to manually check fan margin positioning. The resulting polygons enabled fan area quantification. Using polygons as guides, down fan (apex to toe) profiles were created using DEM line interpolation and profile plotting tools. Profile plots enabled measurement of fan relief and length, allowing fan surface gradient quantification. Fan catchments were extracted from the DEM using the watershed tool, with rasters converted into polygons which were then merged, allowing catchment area quantification. Catchment relief and gradient were quantified using the same approach as described for the fan surface quantification above. Walkover surveys were conducted on various fans across a range of sizes and volcanic geologygeomorphology contexts to verify remote sensing analyses and to provide detailed field insights not possible from remote sensing. The resulting fan location and 
morphometric characteristics of the fans and their catchments (area, relief, length, and gradient) were compiled into a database for morphometric analysis (Supplementary Information 1).

Catchment geology was considered, due to its rock strength-structure-stratigraphy relationships that influence catchment morphology, sediment generation and throughput (connectivity), impacting upon fan process-form relationships (e.g. Mather and Stokes, 2018). Bedrock geology information was derived from the Ancochea et al (2010) map. This was digitised in GIS (Fig. 3) and verified using satellite imagery. Fan catchment geology was extracted within ARC GIS, providing area (\%) breakdowns of the geological units for a given catchment. Rock strength analysis was attempted using in situ Schmidt Hammer field measurements, but allpervasive bedrock surface weathering prevented collection of a meaningful quantitative dataset. Instead, we estimated relative rock strength using generalised slope form-strength relationships (e.g. Goudie, 2016), adopting mean slope angle as a relative indicator of strength, classified into weak (slope $\left.<10^{\circ}\right)$, intermediate $(10-$ $20^{\circ}$ ) and strong (slope $>20^{\circ}$ ) categories (Table 1).

Bivariate regression analysis was used to investigate the morphometric properties of the alluvial fans (dependant variables) and their catchments (independent variables) following standard procedures and equations from alluvial fan research (e.g. Harvey, 2002a; 2011). Fan (F) variables included area (FA) and gradient $(F G)$, whilst Catchment $(C)$ variables included area $(C A)$, relief $(C R)$, length $(C L)$ and gradient (CG). Minitab and Microsoft Excel software were used to plot, verify, and analyse the catchment and fan morphometric properties. Scatterplots were used for qualitative evaluation of data relationships, with use of a $\log 10$ transformation given the wide range of morphological values recorded. Regression lines were fitted to the log10 
data. The regression equation (co-efficient and exponent values) and statistics of the regression model (correlation coefficient, standard error) and its variance (statistical significance p-value at $95 \%$ confidence limits) were collectively used to explore the quality, strength and meaning of the observed relationships. The log residuals (deviations from the predicted best fit line) of the FA vs CA and FG vs CA regressions (e.g. Silva et al., 1992; Harvey, 2002a) were calculated and graphically plotted for exploration of controls on the morphometric properties (i.e. volcano morphology / geology, climate [modern-Quaternary] and base level [fluvial and eustatic]).

\section{Results}

\subsection{Alluvial fan distribution and characteristics}

228 alluvial fans were measured across the island (Fig. 5; Supplementary Information 1), reflecting clearly identifiable fans, with the actual fan numbers being higher. Fans are primarily located along valley side margins in the SW, S and SE of the island interior, with lesser occurrences in the E, NE, and central areas (Fig. 5). Most fans possess a valley axis base-level, but some along the S, SE and NE coasts have a marine base level. Only a few fans are isolated forms. Most are located adjacent to another fan with varying degrees of coalescence with interfan channels defining fan area margins.

Alluvial fan area (min/max: 0.001-1.61 $\left.\mathrm{km}^{2}\right)$, gradient $(0.02-0.31)$ and length (27$2947 \mathrm{~m}$ ) are summarised in Table 3 and detailed graphically in Supplementary 
Information 2. Collectively, these variables show that larger fans tend to be longer and of lower gradient, compared to smaller fans that are shorter with a steeper gradient. Steeper and shorter fans are mostly valley side types (e.g. Fig. 6A), whilst longer and lower gradient forms occur across a wider range of forms (edifice flank, valley side and tributary junctions) in coastal and valley locations (Fig. 6B,C). Alluvial fan plan form geometries vary from lobate, truncated or rhomb-shaped occurrences (Fig. 5) dependant on interactions with neighbouring fans, their interfan drainages and distal fan base level (valley axis stream or coast). Fan surfaces, irrespective of their morphological properties, are often segmented into different lobes differentiated by surface weathering colour and small (m-scale) elevation differences (Fig. 6). Surfaces with higher elevations and more pronounced red-brown colouration typically display relict channel and sediment barform features (Fig. 6B). Most fans display a dominant active channel that is incised by up to several meters from the fan apex to the toe region, with the channel often routed into a downstream interfan area where it connects with the valley axis drainage. This apex to toe entrenchment means the modern fan configuration is one of total incision, lacking any clear spatially variable incision and aggradation patterns often displayed by fans in tectonically active mountain front settings (e.g. Silva et al., 1992; Harvey, 2011). Sediment wise, fans comprise poorly sorted, variably cemented coarse-grained gravels with common cobble-boulder sized clasts. Debris flows dominate smaller fan forms, whilst sediment rich fluvial processes characterise larger fans.

Alluvial fan catchment properties of area $\left(\min / \max =0.01-5.15 \mathrm{~km}^{2}\right)$, gradient $(0.07-$ 0.82), relief (23-654 $\mathrm{m}$ ) and length (76-3050 $\mathrm{m}$ ) are summarised in Table 3 and detailed graphically in Supplementary Information 2. Larger catchment areas are 
typically associated with longer and higher relief properties. Catchment drainage divides often display an angular geometric form bounded by dykes (Fig. 7A). Irrespective of their morphological properties, catchments often display marked sediment backfilling of channels (Fig. 7). Channel backfilling occurs as terraced fills in the lower parts of the catchments, grading to bedrock channels mantled by concentrated boulder accumulations in the steeper slope upper catchment portions (Fig. 7B).

\subsection{Morphometric analysis}

Quantitative morphometric analyses between fan (area [FA], gradient [FG]) and catchment (area $[\mathrm{CA}]$, relief [CR], length $[\mathrm{CL}]$, gradient [CG]) properties are summarised in Table 3 and Figs. 8 and 9. Scatterplots reveal that positive relationships dominate the fan area vs catchment properties, whilst negative relationships typically depict the fan gradient vs catchment characteristics.

Positive relationships exist between $F A$ vs $C A, F A$ vs $C R$, FA vs $C L$ and $F G$ vs $C G$, where increases in 1) fan area are commensurate with increases catchment area, relief and length (Fig. 8), and 2) increase in fan gradient corresponds to an increase in catchment gradient (Fig. 8). Correlation relationships are relatively strong $\left(R^{2}=\right.$ 0.747: $F A$ vs $C A)$ through to moderate $\left(R^{2}=0.436: F G\right.$ vs $\left.C G\right)$, with statistically significant variance (Table 3). The strongest relationship relates to $F A$ vs $C A$ properties $\left(R^{2}=0.747\right)$ and this is in-keeping with findings from broader fan morphometric research (e.g. Harvey, 2011). Analysis of the FA vs CA coefficient 
(0.859) and exponent (0.289) values allows for further exploration of the regression relationship. Values fall within, but at the lower end, of the ranges reported in many dryland fan studies (e.g. coefficients $=0.7$ to 1.1 ; exponent $=0.1$ to 2.1 : Harvey, 2011 and references therein).

Negative relationships exist between FG vs $C A, F G$ vs $C R, F G$ vs $F L$ and $F A$ vs $C G$ where decreases in 1) fan gradient are in-keeping with increases in catchment area, relief and length, 2) decrease in fan area corresponds to an increase in catchment gradient and 3) decrease in fan gradient relates to an increase in fan area (Fig. 9). Correlation coefficients for these negative fan-catchment relationships are weak $\left(R^{2}\right.$ $=0.339$ to 0.130 ) but statistically significant, apart from FG vs CR (Table 3). The FG vs FA analysis, which links to fan building process, confinement and base-level controls, produces the strongest relationship $\left(R^{2}=0.339\right)$. However, coefficient $(-$ $0.149)$ and exponent $(-0.188)$ values fall outside the range of published examples (e.g. coefficients $=0.001$ to 0.062 ; exponents $=-0.466$ to -0.25 : Al-Farraj and Harvey, 2005; Stokes and Mather, 2015).

\subsection{Residual analysis}

Regression residuals represent quantitative deviations from the predicted best line fit. In fan research this commonly involves using residuals generated from the FA and FG versus CA regression analyses (e.g. Harvey, 2002a). Residuals are graphically represented in a scatterplot, and those that plot closest to zero (i.e. graph 
centre) conform to the regression predicted best line fit. Residuals that plot further away from zero represent fans that are oversized or undersized with respect to their area and too steep or too low gradient with respect to their surface slope. This combination of fan area and slope analysis allows fans in this study to be classified into four different area-slope morphological forms: 1) Large Low Gradient (LLG), Small Steep Gradient (SSG), Large Steep Gradient (LSG), Small Low Gradient (SLG) (Fig. 10A). The residual values (Supplementary Information 1) are distributed across a wide range of size and slope combinations, dominated by LLG (39\%) and SSG (28\%) and lesser occurrences of LSG (17\%) and SLG (16\%) (Fig. 10A). Spatial distributions of the residual groups show notable geographical clusters (Fig. 10B-D). All residual groups are associated with a concentration within adjacent SE coast valleys (Palha Carga west [1a] through to Palha Carga East [1b]), the most concentrated area of alluvial fans on the island. LLG fans are restricted along valleys in the west (São Pedro [2a]) and east (Calhau [2b]) and in an inland area (Mindelo lowland [3]). SSG fans shows further clusters in the southwest (Flamengo, Cascavelho and Caixa valleys [4a]) and northeast (Praia Grande coast [5]) of the island. The residual plot (Fig. 10A) also reveals some extreme outliers in the LLG, LSG and SSG groups where fans are 1) large and very low gradient (Min08 and Min09), 2) large and very steep (SL1 and PG6), 3) very small and steep (PG2), and 4) small and very steep (PC6-8, CF1).

\section{Discussion}

\subsection{Fan distribution controls}


Fan formation requires space for fan building and a catchment that supplies sediment to construct the fan, i.e. at mountain fronts, valley sides and tributary junction settings (e.g. Al-Farraj and Harvey, 2005; Harvey, 2011). On a volcanic island, building space occurs around edifice flanks or within edifice incised valleys. Catchments feeding these fans will either comprise drainage that is concordant with the edifice slope to produce the edifice flank fans or drainage that is transverse to the edifice structure feeding the interior valley fans. On São Vicente, only $6 \%$ of fans are located around the island margins, whilst $94 \%$ are developed within the valley drainage networks of the island interior (Section 4.1 and Fig. 5). Space for flank margin fan building could be limited by the steep-sided slope configuration around São Vicente which continues to 3-4000 m water depth (Masson et al., 2008) (Fig. 11). Generally, steep edifice flank slopes promote incision, leading to incised onshore valleys and their offshore canyon continuations (e.g. Llanes et al., 2009). Incision is further enhanced if a volcanic island is undergoing a declining magmatic construction rate (e.g. Paris et al., 2005). The last major edifice construction phase on São Vicente was during the Mio-Pliocene (Ancochea et al., 2010). During the Plio-Pleistocene, a reduction / cessation in volcanic construction rate has enabled erosion to dominate resulting in a lowering of edifice relief from $\sim 2600 \mathrm{~m}$ to $747 \mathrm{~m}$, eroding $\sim 300-400 \mathrm{~km}^{3}$ of edifice material (Ancochea et al., 2010). A significant proportion of this eroded volume is related to giant flank collapses, evidenced from both onshore (NE flank large backscar and widespread landslide breccia of the PGFC: Ancochea et al., 2010) and offshore (southern flank landslide runout / depositional lobes: Masson et al., 2008) locations. The remaining erosion is via stream incision, with subaerial valley formation forming a space conducive for fan building. 
Valleys that incise a volcanic edifice are likely inherited features from the main volcano constructional phases (e.g. Menéndez et al., 2008). Drainage networks will initially develop onto an edifice flank margin, forming a radial pattern away from the volcanic centre (Shelley, 1989; Ollier and Terry, 1999) but with routing modifications linked to continued volcanic growth (Branca and Ferrara, 2001; Branca, 2003). Developing streams will be consequent with the flank margin and the dip slope of its lava-pyroclastic flow constructs, exploiting topographic, rock strength and structure differences between the lava and pyroclastic flows that construct the edifice. Major drainage lines are likely to develop in areas affected by edifice gravitational spreading (Delcamp et al., 2008) or along rift / fracture lines associated with the structural setting of the underlying oceanic plate (Walker, 1999). Valleys on São Vicente are dominantly NE-SW and WSW-ESE, with sub-ordinate NE-SW and NWSE components (Fig. 2). These align with the reconstructed rift structure and its associated dyke systems that fed the São Vicente edifice (Ancochea et al., 2010) (section 2.2). This suggests that the valleys in which alluvial fans are forming have an inherent volcanic structural control on their positioning and development.

Fan residuals (Fig. 10) highlight aspects of the volcanic island structure and related drainage configuration. For example, LLG fans are coincident with major rift valleys (NE-SW São Pedro, upstream part of WNW-ESE Calhau), and the eroded edifice centre (Mindelo). These areas provide the most space for fan building (Fig. 12; Table 4), further illustrated by the LLG residual outliers which show extreme examples of 1) very large and low gradient and 2) large and very low gradient forms (Fig. 10A; section 4.3). SSG fans are associated with smaller edifice flank valleys (Fig. 10D), highlighting the space restrictions of these lesser developed edifice flank draining 
valleys (Fig. 12; Table 4). Again, residual outliers further illustrate some of the more extreme examples of restricted valley space (Fig. 10A; section 4.3). SSG fans are also associated with NE edifice flank margin where coastal fans are foreshortened by rising sea level (e.g. Harvey et al., 1999a). Valleys feeding these coastal fans notably lack fan development along their valley sides. These valleys are narrow and steep, and lacking space for fan building due to flank collapse structure and the relative youthfulness of these valleys compared to elsewhere on the island (Fig. 12; Table 4).

\subsection{Geological controls}

Volcanic rocks, and especially basalts, are highly susceptible to alteration via varying combinations of magmatic, hydrothermal, groundwater and subaerial weathering processes (Berner and Berner, 2012). Thus, fans developed onto younger parts of the São Vicente edifice construct (i.e. USVE and youngest MMC part of the LSVE composite volcano) will be sourcing sediment from relatively stronger less weathered / altered catchment bedrock, in contrast to fans developed into the older and more weathered / altered and therefore weaker core of the edifice (i.e. Basal Complex of the shield volcano and oldest MF part of LVSE composite volcano). In morphometric terms this could influence the morphometric properties of the fan catchments (size, length, gradient), fan depositional areas (valley width, slope) and the resulting fan morphologies (area, gradient), as widely reported in alluvial fan studies (e.g. Hooke and Rohrer, 1977; Calvache et al., 1997; Gómez-Villar et al., 2006; Wang et al., 2008). Stronger rocks will supress fan system morphological development with smaller-steeper catchments with low drainage density, and more confined fan 
depositional settings, with smaller fans built by reduced sediment supply (Mather and Stokes, 2018). In contrast, weaker rocks will enhance fan system morphological development, with larger, less steep catchments with denser drainage networks and less confined fan depositional settings, with larger fans built by enhanced sediment supply (Mather and Stokes, 2018).

Alluvial fan catchment areas are dominated by units of the LSVE (MF $=69 \%$; MMC = $20 \%$ ) with the USVE and SE providing only minor area contributions ( $\mathrm{MV}=7 \%$; $\mathrm{BC}=$ 4\%) (Supplementary information 1). Because the LSVE units dominate the island geology, a geological control on fan morphometric properties is not immediately apparent from the morphometric data (Supplementary Information 1). For example, the widespread nature of Mindelo Formation means that this unit builds fans across a wide range of area and gradient values (Supplementary Information 1). However, the morphometric synthesis offered by the residual analysis reveals some degree of geological control where 1) SSG catchments are dominated by the Monte Verde Formation (54\%), 2) LLG catchments span a wide range of LSVE and SE units and 3) LLG depositional areas have a notable association with the BC of the Sao Vicente Edifice (40\%) (Supplementary Information 1). However, the Monte Verde Formation and Basal Complex have additional base level influences that could equally explain their morphology. Geological controls on fan morphology become clearer when considered in relation to volcanic island structure (section 5.1). This is a fan building confinement control where LLG fans are either related to the more unconfined rift valley or edifice core units associated with the BC and MF units, whilst SSG fans are more related to confined edifice flank and flank collapse regions where a more diverse range of geological units (MF through to RV) occur (Table 4; Fig. 12). 
Although not specifically reflected in the morphometric properties, dykes play an important role in shaping fan catchments. Individual catchments often display an angular geometric configuration that is passively controlled by intersecting dyke swarms (Fig. 7B). Dykes are compositionally different from the surrounding basalt lava flows (Ancochea et al., 2010), with the resulting differences in weathering and erodibility leaving dykes as prominent resistant features that can locally influence stream connectivity and catchment morphology (e.g. Grenfell et al., 2014). Dykes that define the catchment exit and fan apex regions may also enhance channel backfilling of fan sediment into the catchments with morphometric implications (section 5.3).

\subsection{Fan history controls}

The previous discussion highlights that the volcano edifice structure exerts a significant control on fan distribution and fan morphometric properties (section 5.1), whilst edifice geology has modest influence (section 5.2). All fans possess a baselevel, either the coast, valley axis trunk stream or volcanic edifice centre draining streams. Many fans also display distinct (temporally variable?) depositional lobes and channel backfilled catchment areas (Fig. 7). These factors imply that the longerterm history of fans plays a role in their morphometric development (e.g. Harvey, 2011). In the absence of tectonics (Ramalho, et al., 2010; Ramhalo, 2011), fan history will be related to climate and especially climate change, which drives sediment supply, drainage hydrology and base level in fan systems (e.g. Harvey, 1999a,b; 2002; 2011; Stokes and Mather, 2015). 
Fan history helps explain some of the detailed quantitative aspects of the regression results. Fan area and gradient will be affected by base-level, where fan toe erosion is removing fan area, with the resulting smaller and shorter fans leading to steeper surface gradients. Fan and catchment areas will be affected by climate-related sediment supply, where 1) channel sediment backfilling into catchments extends fan areas upstream beyond fan apexes resulting in larger fan areas and smaller catchments and 2) the coalescent nature of fans means that fan areas as defined by interfan channels may not be the best representation of the fan margins. A key observation of the regression results from this volcanic island study is that although the broad positive (e.g. FA vs CA) and negative (e.g. FG vs CA) relationships are inkeeping with fan literature (e.g. Harvey, 2011), correlations are generally poor and coefficient and exponent values are at the lower end or outside of reported values (section 4.2). Most alluvial fan morphometric research is based on unconfined mountain front areas (e.g. Harvey et al., 1999b), with stronger morphometric relationships. The regression results reported here are much more in-keeping with studies of fans from confined settings (e.g. Al-Farraj and Harvey, 2005; Stokes and Mather, 2015).

The base level aspect of fan history on a volcanic island is likely a significant controlling factor for modifying fan morphology. Coastal fans around the edifice flanks, although small in number (6\%), display a strong eustatic base level relationship evidenced by 1) erosional sea cliffs developed into their distal areas (Figs. 4E and 6C), 2) complete fan surface entrenchment with channels linked to modern sea level and 3) marine terraces buried by fan sediment (Fig. 6C). Coastal fans form a notable component of fans with small areas and steep gradients (Fig. 10A). Research into the influence of base-level change on coastal alluvial fans 
highlights the importance of rising Quaternary sea levels for driving fan erosionincision dynamics. This is where fan foreshortening steepens fan surface gradients, promoting surface incision and headwards erosion (Harvey et al., 1999a; Stokes and Garcia, 2009). Although coastal fans are markedly foreshortened, the immediate offshore areas comprise a notable shelf / platform region up to $7 \mathrm{~km}$ wide that levels out to $-100 \mathrm{~m}$ water depth (Fig. 11B-D). Shore platforms are common occurrences around volcanic islands and are attributed to rock strength variation and sub-aerial (lowstand streams, i.e. fans in this instance) and submarine erosion (sand shoal movements controlled by wind) (e.g. Quartau et al., 2010). The São Vicente submarine platform (Fig. 11B-D) is likely an amalgamation of multiple Quaternary sea level lowstands. Edifice flank fans would have undoubtedly extended across this platform. Differences in the degree of distal fan truncation and fan entrenchment between the NE and south coast fans is likely a function of catchment size, slope and sediment supply / storage and local platform morphology / width.

Edifice flank valleys provide a local base-level control for most fans (94\%). Valley floors are alluviated with modest incision of up to several metres (Fig.4C and 6B), suggesting an absence of marked valley base level change in contrast to coastal fans. This probably relates to system scale, with short valley length and small valley catchment areas (Table 4) unable to generate sufficiently large flood discharges capable of major valley floor erosion during the time period of fan development, despite the dryland flash flood setting (Martins et al., 2018). Valley side and tributary fans routinely display fan toe truncation and apex-toe incised fan surface channels that link directly to the trunk valley stream. Truncation and incision are obvious in larger fans or in fans of any size where the active valley axis channel is positioned close to the valley sides (e.g. Figs. 6A, B). Thus, valley floor streams display 
coupling with fan drainages, a key aspect of fan system base level dynamics (Harvey; 2002a,b). This coupling would reduce fan area and steepen fan surfaces impacting on regression results (Figs. 8, 9 and Table 3) as reported in tributary fan studies (Stokes and Mather, 2015). This is especially evident in fan residuals where greater degrees of valley confinement enhance the likelihood of interactions between the fans and the trunk valley drainage (Fig. 12). For example, the undersized and overly steep fans (SSG), and particularly the outliers, are associated with narrower valleys (Figs. 10, 12 and Table 4).

Climate is a further aspect of fan history with relationships to base level, sediment supply and hydrology that may influence fan dynamics over longer (Quaternary) timescales. Evidence for Quaternary fan-climate dynamics is most clear from coastal fans that bury marine terraces (Fig. 6C) or are buried by coastal dunes (Fig. 4E). These relationships suggest that major patterns of fan building, and erosion/incision are cyclic over at least $100 \mathrm{kyr}$ interglacial-glacial timescales, with aggradation occurring during sea level lowering and erosion/incision during rising sea levels (e.g. Harvey et al., 1999a). Valley side and tributary fans lack age control but catchment channel backfilling, fan surface segmentation and incision into fans surfaces and valley floors collectively suggest that fans are currently reflecting a landscape in an erosional state. Catchment hillslopes are not generating sediment and thus sediment supply to the fans is limited. The dryland climate means there is insufficient flood flows to move any available sediment, and any low frequency-high magnitude floods will be dominantly erosional (e.g. Martins et al., 2018). Such climate-related incision and aggradation patterns are routinely reported for dryland alluvial fans and their catchments (e.g. Harvey et al., 2002a; Enzel et al., 2012). Catchment channel backfilling has morphometric implications where fans gain area and have modified 
gradient, whilst catchments lose area, length, and gradient. Channel backfilling may be enhanced by restricted catchment outlets controlled by dike intersections (section 5.2). Finally, the low latitude of Cape Verde $\left(17-14^{\circ} \mathrm{N}\right)$ is within a dryland climate zone affected by precession-related African Humid Periods (Tjallingi et al., 2008). These are short duration ( $5 \mathrm{kyr}$ ) intensely wetter episodes that occur every $20 \mathrm{kyr}$ in relation to Earth's tilt-related wobble. These are likely enhanced periods of sediment generation and transport resulting in fan building, that may be reflected in the different fan lobe segments observed on larger fans whose overall building-erosion patterns are likely related to $100 \mathrm{kyr}$ cycles.

\section{Conclusions}

In this study, we have undertaken a morphometric analysis of dryland alluvial fans on São Vicente, a tectonically quiescent and volcanically inactive island in the Cape Verde volcanic island chain. Morphometric analysis of fan (area, gradient) and catchment (area, relief, gradient, relief) properties are common in dryland mountain front settings but have not been applied to fans on volcanic islands, a landscape where volcanic processes and products provide the geological and geomorphological context for fan development.

Key spatial observations are:

1. Fans are common features on São Vicente volcanic island (x228)

2. Fans occur in 1) coastal areas around the volcanic edifice flanks, 2) within valleys that are incised into the volcanic edifice flanks, along valley sides and in tributary junction settings and 3) in the volcanic centre. 
Key morphometric observations are:

1. Fans and their catchments encompass a range of area, gradient, length, and relief values.

2. Regression analysis of fan and catchment variables show typical positive and negative relationships but with poor correlations and coefficient-exponent values, either outside of or at the lower end of values reported in non-volcanic settings.

3. Residuals using fan area and gradient vs catchment area regressions allowed classification into small (S) or large fans (L) that were steep or low gradient (SG, LG) groups (i.e. SSG, SLG, LSG, LSG).

4. Small and steep gradient (SSG) and large and low gradient (LLG) fan groups dominated, with concentrations into different volcanic island structure contexts with varying influences of rock strength, base level, and climate.

Key controlling points are:

1. Volcanic edifice structure is a fundamental control on fan depositional area confinement. Large low gradient (LLG) fans occur either within 1) the volcanic centre, building out from remnants of the eroded concentric crater into an unconfined central lowland area underlain by weak bedrock or 2 ) in wide edifice flank margins valleys that coincide with major rift structures onto which the volcanic edifice has been constructed. Small steep gradient (SSG) fans occur in 1) coastal settings where rising sea levels have truncated fan toes, fed by catchments developed into edifice flank collapse areas or 2) in narrow valleys developed into the edifice flanks.

2. Volcanic edifice bedrock geology influences fan catchment and depositional areas, where SSG and LLG fans are sourced respectively from stronger and 
weaker/mixed bedrock units, and LLG fans build into areas underlain by weaker bedrock.

3. Base level is an important control, interacting with the volcanic edifice structure and climate. It is important in both coastal and valley confinement contexts by modifying fan morphologies. In coastal contexts, sea level erodes distal fan areas, leading to undersized and steeper than expected fans. In valley confinement contexts fan toe erosion is amplified by dryland flash flood dynamics, leading to undersized and steeper than expected fans.

4. The modern dryland climate is currently limiting fan catchment sediment generation and transfer leading to catchment channel backfilling, thus adding to fan areas but reducing catchment area size.

5. Quaternary climate plays a longer-term fan history role, influencing flank margin eustatic base-level changes as a fan space building factor and driving major periods of fan building and erosion via sediment-water flux variations.

Although based on analysis of alluvial fans from a single volcanic island, this study suggests that the morphometric properties of volcanic island fans have similarities and differences to fans from non-volcanic island settings. Volcanic island fans are most likely to develop within edifice flank margin valleys, which provides a space that dictates fan size and gradient, but also a local base level that can modify size / gradient. These valley margin fans are more typical of tributary junction fans in the broader fan literature. Fans that build in the volcanic centre of an island are more inkeeping with mountain front fans due to low lateral and distal confinement. Fans that build around volcanic edifice margins are less common. They are likely more inkeeping with mountain front fans but are highly prone to marine erosion, especially during rising sea levels that reduces their fan areas and steepens their fan gradients. 


\section{Acknowledgements}

We thank Shaun Lewin for GIS advice, Rosa Rocha for local Sao Vicente support, the British Society for Geomorphology, Quaternary Research Association, University of Plymouth, and Porto University for financially supporting fieldwork, and DLR for providing TAN-DEM-X data (Project: DEM_HYDR0870). The reviewers (anonymous, Adrian Harvey, Pablo Silva) and editor (Scott Lecce) are all thanked for their insightful improvement suggestions.

\section{References}

Al-Farraj, A., Harvey, A.M., 2005. Morphometry and depositional style of Late Pleistocene alluvial fans: Wadi Al-Bih, northern UAE and Oman. In: Harvey, A.M., Mather, A.E., Stokes, M. (Eds.), Alluvial Fans: Geomorphology, Sedimentology, Dynamics. Geological Society, London, Special Publications 251, pp. 85-94.

Ancochea, E., Huertas, M.J., Hernán, F., Brändle, J.L., 2010. Volcanic evolution of São Vicente, Cape Verde Islands: The Praia Grande landslide. Journal of Volcanology and Geothermal Research 198, 143-157.

Bahrami, S., 2013. Tectonic controls on the morphometry of alluvial fans around Danehkhoshk anticline, Zagros, Iran. Geomorphology 180-181, 217-230.

Berner, E.K., Berner, R.A., 2012. Global Environment: Water, Air, and Geochemical Cycles. Princeton University Press. $2^{\text {nd }}$ Edition. 464p. 
Blair, T.C., McPherson, J.G., 2009. Alluvial fan processes and forms. In: Parsons, A. Abrahams, A.D., (Eds). Geomorphology of Desert Environments. $2^{\text {nd }}$ Edition. Springer, 413-467.

Bowman, D., 2019. Principles of Alluvial Fan Morphology. Springer, 151p. https://doi.org/10.1007/978-94-024-1558-2

Branca, S., 2003. Geological and geomorphological evolution of the Etna volcano NE flank and relationships between lava flow invasions and erosional processes in the Alcantara Valley (Italy). Geomorphology 53, 247-261.

Branca, S., Ferrara, V., 2001. An example of river pattern evolution produced during the lateral growth of a central polygenic volcano: the case of the Alcantara river system, Mt Etna (Italy). Catena, 45, 85-102.

Bull, W.B., 1977. The alluvial fan environment. Progress in Physical Geography 1, 222-270.

Calvache, M.L., Viseras, C. Fernand́ez, J., 1997. Controls on fan developmentevidence from fan morphometry and sedimentology; Sierra Nevada, SE Spain. Geomorphology 21, 69-84.

de Silva, S., Lindsay, J.M., 2015. Primary Volcanic Landforms. In: Sigurdsson, H., Houghton, B., McNutt, S., Rymer, H., Stix, J. (Eds.). The Encyclopedia of Volcanoes. $2^{\text {nd }}$ Edition, Academic Press. pp. 273-297.

Delcamp, A., de Vries, B.V.W., James, M.R., 2008. The influence of edifice slope and substrata on volcano spreading. Journal of Volcanology and Geothermal Research 177, 925-943. 
DLR, 2016. https://tandemx-science.dlr.de/ [accessed 05/04/20]

Duarte, M.C., Romeiras, M.M., 2009. Cape Verde Islands. In: Gillespie, R.G. and Clague, D.A. (Eds.), The Encyclopedia of Islands. Univ of California Press. pp.143148.

Enzel, Y., Amit, R., Grodek, T., Ayalon, A., Lekach, J., Porat, N., Bierman, P., Blum, J.D., Erel, Y., 2012. Late Quaternary weathering, erosion, and deposition in Nahal Yael, Israel: An "impact of climatic change on an arid watershed"?. Geological Society of America, Bulletin 124, 705-722.

Field, J., 2001. Channel avulsion on alluvial fans in southern Arizona. Geomorphology 37, 93-104.

GEBCO, 2020. https://www.gebco.net/data_and_products/gridded_bathymetry_data/ [accessed 04/05/2020]

Gómez-Villar, A., Álvarez-Martínez, J., García-Ruiz, J.M., 2006. Factors influencing the presence or absence of tributary-junction fans in the Iberian Range, Spain. Geomorphology 81, 252-264.

Goudie, A.S., 2016. Quantification of rock control in geomorphology. Earth-Science Reviews 159, 374-387.

Grenfell, S.E., Grenfell, M.C., Rowntree, K.M., Ellery, W.N., 2014. Fluvial connectivity and climate: A comparison of channel pattern and process in two climatically contrasting fluvial sedimentary systems in South Africa. Geomorphology 205, 42-154. 
Harvey, A.M., 2002a. The role of base-level change in the dissection of alluvial fans: case studies from southeast Spain and Nevada. Geomorphology 45, 67-87.

Harvey, A.M., 2002b. Effective timescales of coupling within fluvial systems. Geomorphology 44, 175-201.

Harvey, A.M., 2011. The role of alluvial fans in arid zone fluvial systems. In: Thomas, D.S.G. (Ed.), Arid Zone Geomorphology: Process, Form and Change in Drylands. $3^{\text {rd }}$ Edition. Wiley, pp. 333-371.

Harvey, A.M., Mather, A.E., Stokes, M., 2005. Alluvial fans: geomorphology, sedimentology, dynamics - Introduction. A review of alluvial-fan research. Geological Society, London, Special Publications, 251, pp.1-7.

Harvey, A.M., Silva, P.G., Mather, A.E., Goy, J.L., Stokes, M., Zazo, C., 1999a. The impact of Quaternary sea-level and climatic change on coastal alluvial fans in the Cabo de Gata ranges, southeast Spain. Geomorphology 28, 1-22.

Harvey, A.M., Wigand, P.E., Wells, S.G., 1999b. Response of alluvial fan systems to the late Pleistocene to Holocene climatic transition: contrasts between the margins of pluvial Lakes Lahontan and Mojave, Nevada and California, USA. Catena 36, 255281.

Holm, P.M., Grandvuinet, T., Friis, J., Wilson, J.R., Barker, A.K., Plesner, S., 2008. An 40Ar-39Ar study of the Cape Verde hot spot: Temporal evolution in a semistationary plate environment. Journal of Geophysical Research: Solid Earth, 113(B8). 
Hooke, R.L., Rohrer, R., 1977. Relative erodibility of source-area rock types, as determined from second-order variations in alluvial-fan size. Geological Society of America, Bulletin 88, 1177-1182.

Llanes, P., Herrera, R., Gómez, M., Muñoz, A., Acosta, J., Uchupi, E., Smith, D., 2009. Geological evolution of the volcanic island La Gomera, Canary Islands, from analysis of its geomorphology. Marine Geology 264, 123-139.

Martins, B., Lourenço, L., Monteiro, S., 2018. Natural Hazards in São Vicente (Cabo Verde). Journal of Environmental Geography 11, 1-8.

Masson, D.G., Le Bas, T.P., Grevemeyer, I., Weinrebe, W., 2008. Flank collapse and large-scale landsliding in the Cape Verde Islands, off West Africa. Geochemistry, Geophysics, Geosystems, 9(7).

Mather, A.E., Stokes, M., 2018. Bedrock structural control on catchment-scale connectivity and alluvial fan processes, High Atlas Mountains, Morocco. In: Ventra, D., Clarke, L.E., (Eds.). Geology and Geomorphology of Alluvial and Fluvial Fans: Terrestrial and Planetary Perspectives. Geological Society, London, Special Publications 440, pp.103-128.

Mather, A.E., Harvey, A.M., Stokes, M., 2000. Quantifying long-term catchment changes of alluvial fan systems. Geological Society of America Bulletin 112, 18251833.

Mather, A.E., Stokes, M., Whitfield, E., 2017. River terraces and alluvial fans: the case for an integrated Quaternary fluvial archive. Quaternary Science Reviews 166, 74-90. 
Menéndez, I., Silva, P.G., Martín-Betancor, M., Pérez-Torrado, F.J., Guillou, H., Scaillet, S., 2008. Fluvial dissection, isostatic uplift, and geomorphological evolution of volcanic islands (Gran Canaria, Canary Islands, Spain). Geomorphology 102, 189203.

Mitchell, N.C., 1998. Characterising the irregular coastlines of volcanic ocean islands. Geomorphology 23, 1-14.

Ollier, C.D., Terry, J.P., 1999. Volcanic geomorphology of northern Viti Levu, Fiji. Australian Journal of Earth Sciences 46, 515-522.

Paris, R., Guillou, H., Carracedo, J.C., Torrado, F.P., 2005. Volcanic and morphological evolution of La Gomera (Canary Islands), based on new K-Ar ages and magnetic stratigraphy: implications for oceanic island evolution. Journal of the Geological Society 162, 501-512.

Pim, J., Peirce, C., Watts, A.B., Grevemeyer, I., Krabbenhöft, A., 2008. Crustal structure and origin of the Cape Verde Rise. Earth and Planetary Science Letters $272,422-428$.

Plesner, S., Holm, P.M., Wilson, J.R., 2002. 40Ar-39Ar geochronology of Santo Antão, Cape Verde Islands. Journal of Volcanology and Geothermal Research, 120, $103-121$.

Pollitz, F.F., 1991. Two-stage model of African absolute motion during the last 30 million years. Tectonophysics 194, 91-106.

Quartau, R., Trenhaile, A.S., Mitchell, N.C., Tempera, F., 2010. Development of volcanic insular shelves: Insights from observations and modelling of Faial Island in the Azores Archipelago. Marine Geology 275, 66-83. 
Ramalho, R.A.S., 2011. Building the Cape Verde Islands. Springer Theses, Springer-Verlag Berlin Heidelberg. 210p.

Ramalho, R., Helffrich, G., Schmidt, D.N., Vance, D., 2010. Tracers of uplift and subsidence in the Cape Verde Archipelago. Journal of the Geological Society 167, 519-538.

Read, K.A., 2010. Cape Verde Atmospheric Observatory. NCAS British Atmospheric Data Centre. Accessed 13/01/2020.

https://catalogue.ceda.ac.uk/uuid/3672d794898c42908ca08f6ba32591ac

Shelley, D., 1989. Anteconsequent drainage: an unusual example formed during constructive volcanism. Geomorphology 2, 363-367.

Silva, P.G., Harvey, A.M., Zazo, C., Goy, J.L., 1992. Geomorphology, depositional style and morphometric relationships of Quaternary alluvial fans in the Guadalentin Depression (Murcia, Southeast Spain). Zeitschrift für Geomorphologie 36, 325-341.

Stokes, M., García, A.F., 2009. Late Quaternary landscape development along the Rancho Marino coastal range front (south-central Pacific Coast Ranges, California, USA). Journal of Quaternary Science 24, 728-746.

Stokes, M., Mather, A.E., 2015. Controls on modern tributary-junction alluvial fan occurrence and morphology: high Atlas Mountains, Morocco. Geomorphology 248, 344-362.

Thouret, J.C., 1999. Volcanic geomorphology - an overview. Earth-Science Reviews, 47, 95-131. 
Tjallingii, R., Claussen, M., Stuut, J.B.W., Fohlmeister, J., Jahn, A., Bickert, T., Lamy, F., Röhl, U., 2008. Coherent high-and low-latitude control of the northwest African hydrological balance. Nature Geoscience 1, 670-675.

USGS, 2020. https://earthexplorer.usgs.gov/ [accessed 04/05/20]

Vinnik, L., Silveira, G., Kiselev, S., Farra, V., Weber, M., Stutzmann, E., 2012. Cape Verde hotspot from the upper crust to the top of the lower mantle. Earth and Planetary Science Letters 319, 259-268.

Viseras, C., Calvache, M.L., Soria, J.M., Fernández, J., 2003. Differential features of alluvial fans controlled by tectonic or eustatic accommodation space. Examples from the Betic Cordillera, Spain. Geomorphology 50, 181-202.

Walker, G.P., 1999. Volcanic rift zones and their intrusion swarms. Journal of Volcanology and Geothermal Research 94, 21-34.

Wang, H., Harvey, A.M., Xie, S., Kuang, M., Chen, Z., 2008. Tributary-junction fans of China's Yangtze Three-Gorges valley: morphological implications.

Geomorphology 100, 131-139.

Williams, C.A., Hill, I.A., Young, R., White, R.S., 1990. Fracture zones across the Cape Verde rise, NE Atlantic. Journal of the Geological Society 147, 851-857. 
Table 1 Summary of bedrock geology units (Ancochea et al., 2010), their area and slope configurations and rock strength relationships.

Table 2 Summary morphometric properties of alluvial fans and their catchments $(\mathrm{n}=$ 228). See Fig. 5 for spatial distribution and Supplementary Information 1 for fan specific values.

Table 3 Regression results and their statistical significance for fan and catchment variables. $\mathrm{SE}=$ standard error $\mathrm{P}=$ statistical significance. See Figs. 8 and 9 for graphical representation.

Table 4 Valley morphological and geological characteristics with alluvial fan contexts. ${ }^{a}$ Calhau valley is likely part rift valley (upstream) and edifice flank valley (downstream), here included as an edifice flank valley due to uncertainty. ${ }^{1}$ Santa Luzia fans excluded due to edifice flank, coastal setting; ${ }^{2}$ Average valley area, width, length, and stream orders. $\mathrm{BC}=$ Basal Complex; $\mathrm{MF}=$ Mindelo Formation, $\mathrm{MMC}-$ Madeiral-Monte Cara Formation, RV = Recent Volcanics. LLG = Large Low Gradient and SSG = Small Steep Gradient fans.

Figure 1 A) Atlantic Ocean, Mid Ocean Ridge and African continent contexts of the Cape Verde islands. B) Cape Verde (major) islands: SA = Santo Antão; SV = São Vicente (circled); SN = São Nicolau; SI = Sal; BV = Boa Vista; M = Maio; St = Santiago; F = Fogo; B = Brava. Sea floor DEM uses GEBCO_2020 gridded bathymetry data (GEBCO, 2020). Landmass topography uses SRTM 3 and 1 arc second data (USGS, 2020). 
Figure 2 São Vicente topography, drainage network $\left(2^{\text {nd }}-4^{\text {th }}\right.$ order streams [Strahler] $)$ (A) and slope (B). Locations: $\mathrm{M}=$ Mindelo; $\mathrm{L}=$ Lazareto; $\mathrm{SP}=$ São Pedro; $\mathrm{C}=$ Calhau; $B d G=$ Baia das Gatas; $S$ = Salamansa.

Figure 3 São Vicente geology map (A) and cross-section (B). Line of cross-section = A-A' in Fig. 3A. Modified from Ancochea et al., (2010).

Figure 4 São Vicente geological and geomorphological field imagery. A) View NW across lowland island interior shield volcano landscape (BC) and the overlying composite volcano edifice remnant (LSVE). B) Dipping lava flows of the composite volcano (LSVE) viewed from Mindelo Bay towards Monte Cara peak (483 m). C) View WSW across the alluvial valley fill (AVF) of a Palha Carga south coast valley ('Carga East' in fan database) towards the dipping lava flows of the composite volcano and its Madeiral peak (677 m). D) $\sim 12 \mathrm{~m}$ elevation Pleistocene marine terrace (MT) and overlying coastal alluvial fan, SE São Vicente. E) Praia Grande coast (NE São Vicente) comprising composite volcano lava flows (MV) and flank collapse region, with aeolian dunes (Aeo.) and a coastal alluvial (Fan) in the foreground. F) Strombolian cone (RV), Calhau region (SE São Vicente). Aeo. $=$ Pleistocene aeolian sands; RV $=$ Recent Volcanics $;$ USVE $=$ Upper São Vicente Edifice; MV = Monte Verde Formation; LSVE = Lower São Vicente Edifice; $\mathrm{MMC}=$ Madeiral-Monte Cara Formation; $\mathrm{M}=$ Madeiral Formation; $\mathrm{BC}=$ Basal Complex. See Table 1.

Figure 5 Spatial distribution of alluvial fans and catchments. Valley regions referred to in text and Supplementary Information $1: \mathrm{SP}=\mathrm{São}$ Pedro; $\mathrm{F}=$ Flamengo; $\mathrm{CF}=$ 
Cascavelho; C = Caixa; $\mathrm{A}=$ Araújo; Cal = Calheta; CW = Carga West, $\mathrm{CWC}=$ Carga West Central; $\mathrm{CEC}=$ Carga East Central; $\mathrm{CE}=$ Carga East; $\mathrm{PC}=$ Palha Carga; $\mathrm{SL}=$ Santa Luzia; $\mathrm{Clh}=$ Calhau; $\mathrm{PG}=$ Praia Grande; $\mathrm{M}=$ Mindelo .

Figure 6 Alluvial fan field imagery. Fan margins depicted by white dashed lines. A) Small-steep fan building from interior valley side, south coast (CEC26 [Fan ID]: $24.951587 ; 16.797633$ ). Note distal fan truncation by valley axis stream (white arrows). Field of view $=\sim 250 \mathrm{~m}$. B) Tributary junction fan developed at a south coast interior valley tributary junction (CEC6: -24.962284; 16.80705). Note relict channelbar network (r-c-b-n) developed onto an elevated, darker coloured fan surface lobe and inset active channel $(\mathrm{a}-\mathrm{c})$. Field of view $=\sim 250 \mathrm{~m}$. C) Large (SE) coastal alluvial fan (SL3: -24.905460; 16.818749). Note truncated distal fan region (sea cliffs - sc) due to marine erosion and channel incision (a-c) into the fan surface comprising a relict channel-bar network and dark colouration ( $r-c-b-n)$. Field of view $=\sim 1500 \mathrm{~m}$.

Figure 7 Alluvial fan catchment imagery. A) West facing oblique Google Earth image (CNES/Airbus/Maxar Technologies/Landsat/Copernicus) of a valley side fan (AF12 [Fan ID]: -25.048696; 16.850681) showing dyke-controlled catchment geometry and extensive channel sediment backfilling (b-f). Dashed white lines $=$ dyke examples. White arrow = fan apex. B) View downstream through the mid and distal parts of a fan catchment area (SL3: -24.905460; 16.818749) showing dyke (d) controlled backfilled channel sediment (bf). White arrow = fan apex.

Figure 8 Positive morphometric relationships of fan and catchment variables ( $A=F A$ vs $C A ; B=F A$ vs $C R ; C=F G$ vs $C G ; D=F A$ vs $C L)$. See Table 3 for summary regression statistics. 
Figure 9 Negative morphometric relationships of fan and catchment variables $(A=$ FG vs $C A ; B=F G$ vs $C R ; C=F A$ vs $C G ; D=F G$ vs $C L ; E=F G$ vs $F A)$. See Table 3 for summary regression statistics.

Figure 10 A) Scatterplot of residual values and size-slope groupings, with notable outliers labelled. B) Spatial distribution of residual groups, with notable south coast cluster [1]. C) LLG clusters associated with major rift valleys [2ab] and edifice volcanic centre [3]. D) SSG clusters associated with edifice flank valley sides [4] and the flank collapse region (PGFC) [5].

Figure 11 Sea floor profiles (GEBCO, 2020). A) Regional São Vicente-abyssal plain perspective. B) -100 m contour / platform position and profile line locations, noting 11' (A) extends beyond the map extent. C-E) Detailed profiles along SE, SW and NE edifice flanks regions associated with alluvial fans, noting circa island submarine platform to $\sim 100 \mathrm{~m}$ and PGFC landslide morphology.

Figure 12 A volcanic island fan building space model based on São Vicente, illustrating valley forms from different volcanic edifice and bedrock erosion contexts. Map notation $-\mathrm{VC}=$ volcanic centre; $\mathrm{RV}=$ rift valley; $\mathrm{EF}=$ edifice flank; $\mathrm{PGFC}=$ Praia Grande flank collapse. See Table 4 for summary valley morphometric quantification. 
Table 1

\begin{tabular}{|c|c|c|c|c|c|c|c|c|c|c|}
\hline & \multicolumn{2}{|c|}{ Area } & \multirow{2}{*}{$\begin{array}{c}\text { Mea } \\
\text { n } \\
\text { slop } \\
e \\
\circ\end{array}$} & \multirow{2}{*}{$\begin{array}{c}\text { Max } \\
\text { slop } \\
\text { e } \\
0\end{array}$} & \multirow[t]{2}{*}{$\begin{array}{c}\text { Rock } \\
\text { strength }\end{array}$} & \multicolumn{2}{|c|}{$\begin{array}{c}\text { Fan } \\
\text { catchme } \\
\text { nt area }\end{array}$} \\
\hline & & & & $\mathrm{km}_{2}$ & $\%$ & & & & $\mathrm{~km}_{2}$ & $\%$ \\
\hline \multicolumn{2}{|c|}{ Pleistocene } & \multicolumn{2}{|c|}{$\begin{array}{l}\text { Aeolian } \\
\text { sediments } \\
\text { (Aeo.) }\end{array}$} & 1 & $\begin{array}{l}< \\
1\end{array}$ & - & - & $\mathrm{n} / \mathrm{a}$ & - & - \\
\hline $\begin{array}{l}\text { Pleistoce } \\
\text { ne }\end{array}$ & \multirow{5}{*}{$\begin{array}{l}\text { São } \\
\text { Vicente } \\
\text { Edifice } \\
\text { (SVE) }\end{array}$} & \multicolumn{2}{|c|}{$\begin{array}{l}\text { Recent } \\
\text { Volcanics (RV) }\end{array}$} & 18 & 8 & 4 & 68 & weak & - & - \\
\hline \multirow[t]{2}{*}{$\begin{array}{l}\text { Plio- } \\
\text { Pleistoce } \\
\text { ne }\end{array}$} & & $\begin{array}{l}\text { Upper } \\
\text { São } \\
\text { Vicent } \\
\text { e } \\
\text { Edific } \\
\text { e } \\
\text { (USV } \\
\text { E) }\end{array}$ & $\begin{array}{l}\text { Monte } \\
\text { Verde } \\
\text { Fm } \\
(\mathrm{MV})\end{array}$ & 38 & $\begin{array}{l}1 \\
7\end{array}$ & 19 & 81 & $\begin{array}{l}\text { intermedi } \\
\text { ate }\end{array}$ & 17 & 29 \\
\hline & & \multicolumn{2}{|c|}{$\begin{array}{c}\text { Praia Grande } \\
\text { Flank Collapse } \\
\text { (PGFC) }\end{array}$} & & & & & & & \\
\hline \multirow[t]{2}{*}{$\begin{array}{l}\text { Mio- } \\
\text { Pliocene }\end{array}$} & & $\begin{array}{l}\text { Lower } \\
\text { São } \\
\text { Vicent } \\
\text { e } \\
\text { Edific } \\
\mathrm{e}\end{array}$ & $\begin{array}{l}\text { Madeir } \\
\text { al- } \\
\text { Monte } \\
\text { Cara } \\
\text { Fm } \\
\text { (MMC) }\end{array}$ & 21 & $\begin{array}{l}1 \\
0\end{array}$ & 34 & 86 & strong & 8 & 14 \\
\hline & & $\begin{array}{l}\text { (LSV } \\
\text { E) }\end{array}$ & $\begin{array}{l}\text { Mindel } \\
\text { o Fm } \\
\text { (MF) }\end{array}$ & $\begin{array}{c}10 \\
2\end{array}$ & $\begin{array}{l}4 \\
5\end{array}$ & 15 & 82 & $\begin{array}{l}\text { intermedi } \\
\text { ate }\end{array}$ & 30 & 51 \\
\hline Miocene & $\begin{array}{l}\text { Submari } \\
\text { ne } \\
\text { Edifice } \\
\text { (SE) }\end{array}$ & \multicolumn{2}{|c|}{$\begin{array}{l}\text { Basal Complex } \\
\text { (BC) }\end{array}$} & 45 & $\begin{array}{l}2 \\
0\end{array}$ & 7 & 47 & weak & 4 & 7 \\
\hline
\end{tabular}


Table 2

\begin{tabular}{|c|c|c|c|c|c|c|c|}
\hline & \multicolumn{3}{|c|}{ Alluvial fans } & \multicolumn{4}{|c|}{ Catchments } \\
\hline & $\begin{array}{l}\text { Area } \\
\left(\mathrm{km}^{2}\right)\end{array}$ & $\begin{array}{l}\text { Gradient } \\
\text { (dimensionl } \\
\text { ess) }\end{array}$ & $\begin{array}{l}\text { Leng } \\
\text { th } \\
\text { (m) }\end{array}$ & $\begin{array}{l}\text { Area } \\
\left(\mathrm{km}^{2}\right. \\
)^{2}\end{array}$ & $\begin{array}{l}\text { Reli } \\
\text { ef } \\
\text { (m) }\end{array}$ & $\begin{array}{l}\text { Gradient } \\
\text { (dimensionl } \\
\text { ess) }\end{array}$ & $\begin{array}{l}\text { Leng } \\
\text { th } \\
\text { (m) }\end{array}$ \\
\hline Mean & 0.12 & 0.12 & 420 & 0.27 & 183 & 0.40 & 522 \\
\hline Max & 1.61 & 0.31 & 2947 & 5.15 & 654 & 0.82 & 3050 \\
\hline Min & $\begin{array}{l}0.00 \\
1\end{array}$ & 0.02 & 27 & 0.01 & 23 & 0.07 & 76 \\
\hline $\begin{array}{l}\text { Standard } \\
\text { deviation }\end{array}$ & 0.24 & 0.07 & 461 & 0.59 & 124 & 0.12 & 480 \\
\hline
\end{tabular}


Table 3

\begin{tabular}{llllll}
\hline Dependent vs. independent variables & Coefficient & Exponent & $\mathrm{R}^{2}$ & $\mathrm{SE}$ & $\mathrm{P}$ \\
\hline Fan area vs. catchment area & 0.859 & 0.289 & 0.747 & 0.392 & 0 \\
Fan gradient vs. catchment area & -0.152 & -0.243 & 0.228 & 0.221 & 0 \\
Fan area vs. catchment relief & 0.731 & 1.71 & 0.454 & 0.576 & 0 \\
Fan gradient vs. catchment relief & -0.773 & -0.096 & 0.137 & 0.25 & 0.07 \\
Fan area vs. catchment gradient & 3.68 & -1.776 & 0.130 & 0.727 & 0 \\
Fan gradient vs. catchment gradient & -0.538 & 1.049 & 0.436 & 0.189 & 0 \\
Fan gradient vs. catchment length & -0.171 & -0.313 & 0.175 & 0.288 & 0 \\
Fan area vs. catchment length & -0.290 & 1.826 & 0.619 & 0.482 & 0 \\
Fan gradient vs. fan area & -0.149 & -0.188 & 0.339 & 0.204 & 0 \\
\hline
\end{tabular}


Table 4

\begin{tabular}{|c|c|c|c|c|c|c|c|c|c|}
\hline $\begin{array}{l}\text { Valley } \\
\text { setting }\end{array}$ & $\begin{array}{l}\text { No. } \\
\text { valleys }\end{array}$ & $\begin{array}{l}{ }^{1} \text { No. } \\
\text { fans }\end{array}$ & $\begin{array}{l}{ }^{2} \text { Valley } \\
\text { area } \\
\left(\mathrm{km}^{2}\right)\end{array}$ & $\begin{array}{l}{ }^{2} \text { Valley } \\
\text { length } \\
(\mathrm{km})\end{array}$ & $\begin{array}{l}{ }^{2} \text { Valley } \\
\text { width } \\
(\mathrm{km})\end{array}$ & $\begin{array}{l}\text { Peak } \\
\text { height } \\
\text { range } \\
\text { (m) }\end{array}$ & $\begin{array}{l}{ }^{2} \text { Stream } \\
\text { order }\end{array}$ & Geology & $\begin{array}{l}\text { Main } \\
\text { fan } \\
\text { group }\end{array}$ \\
\hline $\begin{array}{l}\text { Rift } \\
\text { Valley }\end{array}$ & 1 & 18 & 15 & 4.4 & 1 & $244-571$ & 3 & $\begin{array}{l}\mathrm{MCM}=13 \% \\
\mathrm{MF}=87 \%\end{array}$ & LLG \\
\hline $\begin{array}{l}\text { Edifice } \\
\text { flank } \\
\text { valleys }^{a}\end{array}$ & 11 & 180 & 7 & 3.9 & 0.3 & $180-697$ & 2 & $\begin{array}{l}\mathrm{RV}=1 \% \\
\mathrm{MV}=4 \% \\
\mathrm{MCM}=14 \% \\
\mathrm{MF}=81 \%\end{array}$ & SSG \\
\hline $\begin{array}{l}\text { Flank } \\
\text { collapse } \\
\text { valleys }\end{array}$ & 7 & 7 & 1.3 & 2 & 0.1 & $209-774$ & 1 & $M V=100 \%$ & SSG \\
\hline $\begin{array}{l}\text { Volcanic } \\
\text { centre }\end{array}$ & 1 & 14 & 54 & 7.5 & 1.3 & $244-774$ & 4 & $\begin{array}{l}\mathrm{MCM}=12 \% \\
\mathrm{MF}=12 \% \\
\mathrm{BC}=76 \%\end{array}$ & LLG \\
\hline
\end{tabular}




\section{Declaration of interests}

$\bigotimes$ The authors declare that they have no known competing financial interests or personal relationships that could have appeared to influence the work reported in this paper.

$\square$ The authors declare the following financial interests/personal relationships which may be considered as potential competing interests: 


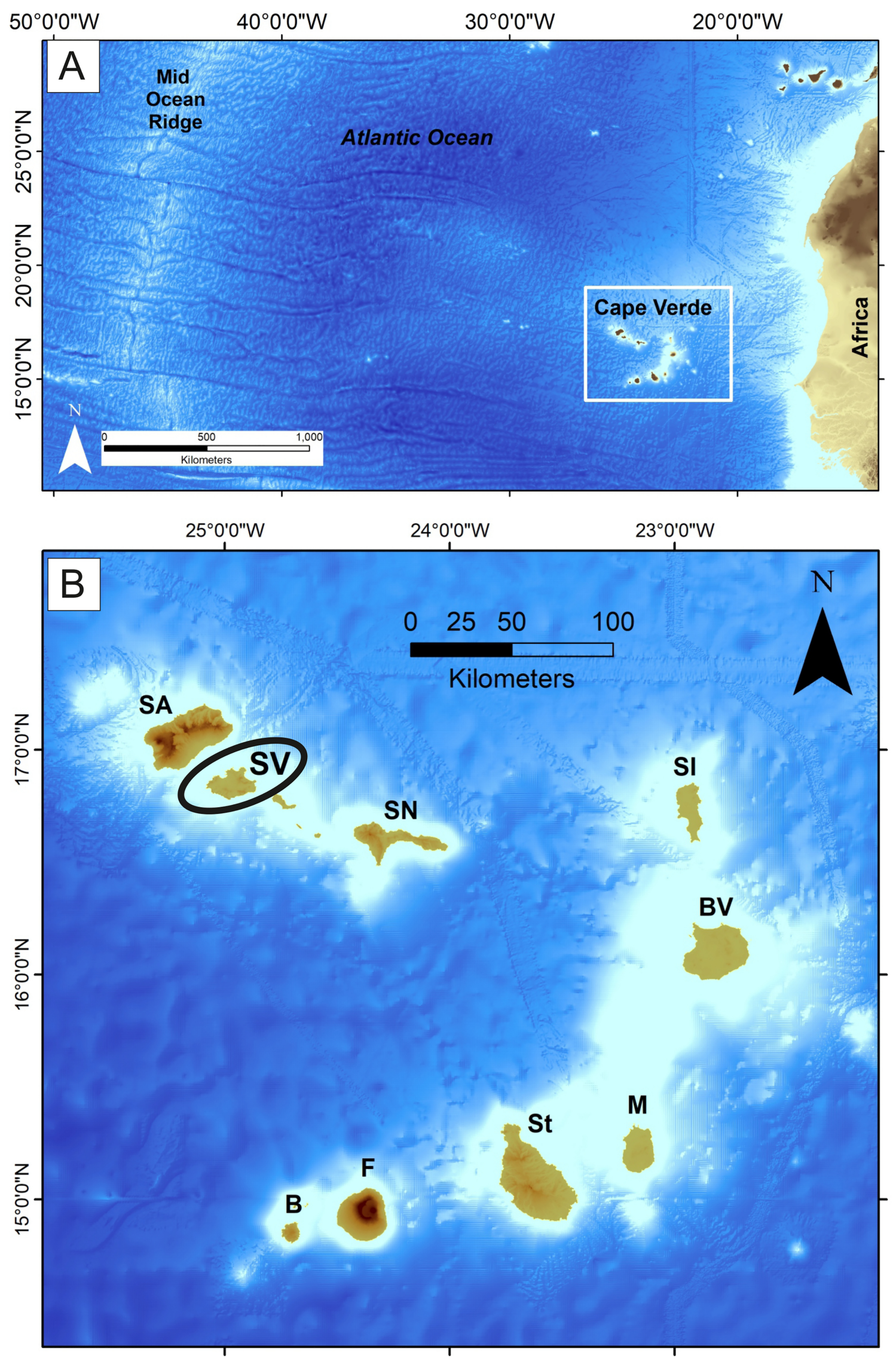



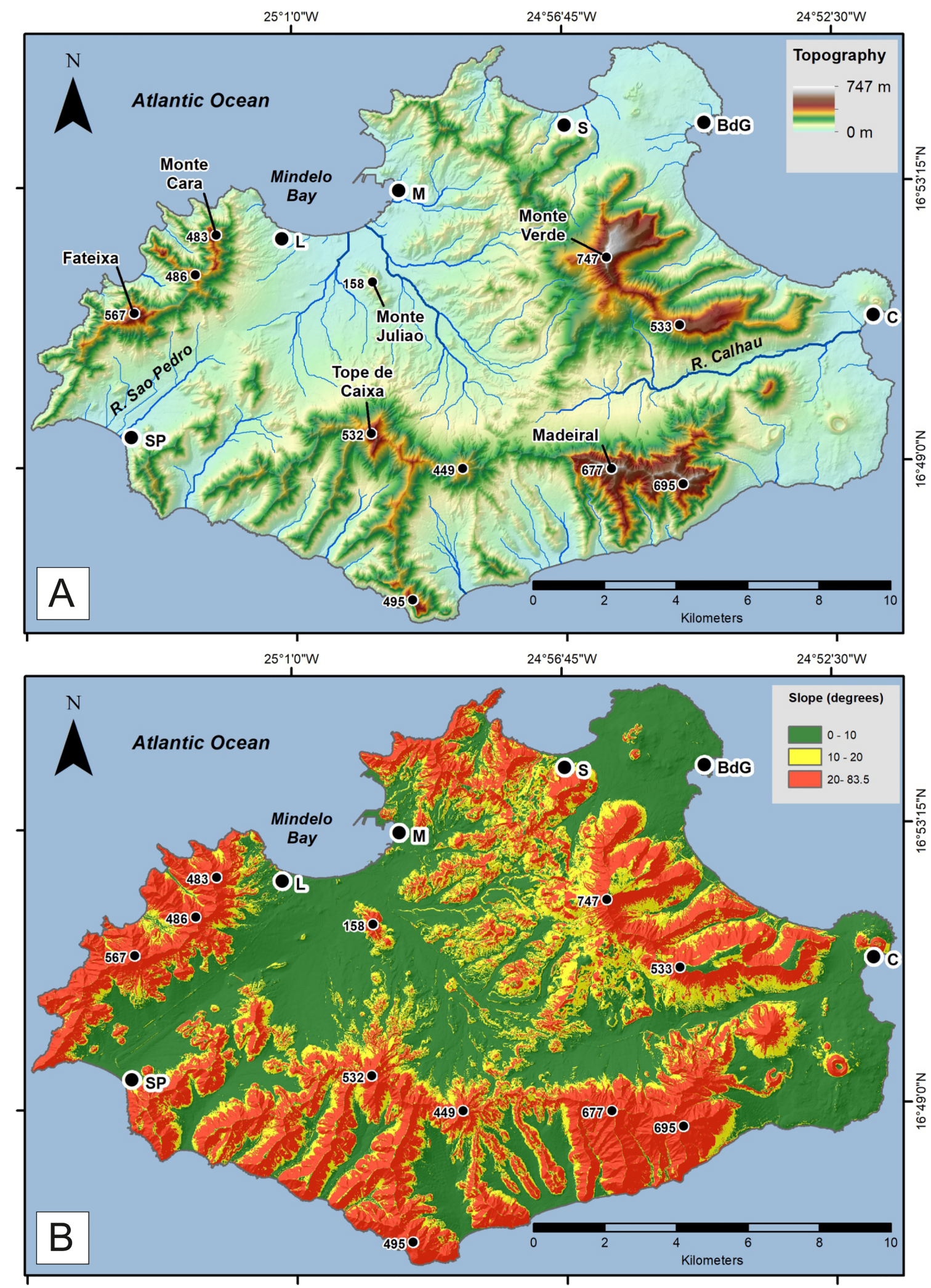

Figure 2 

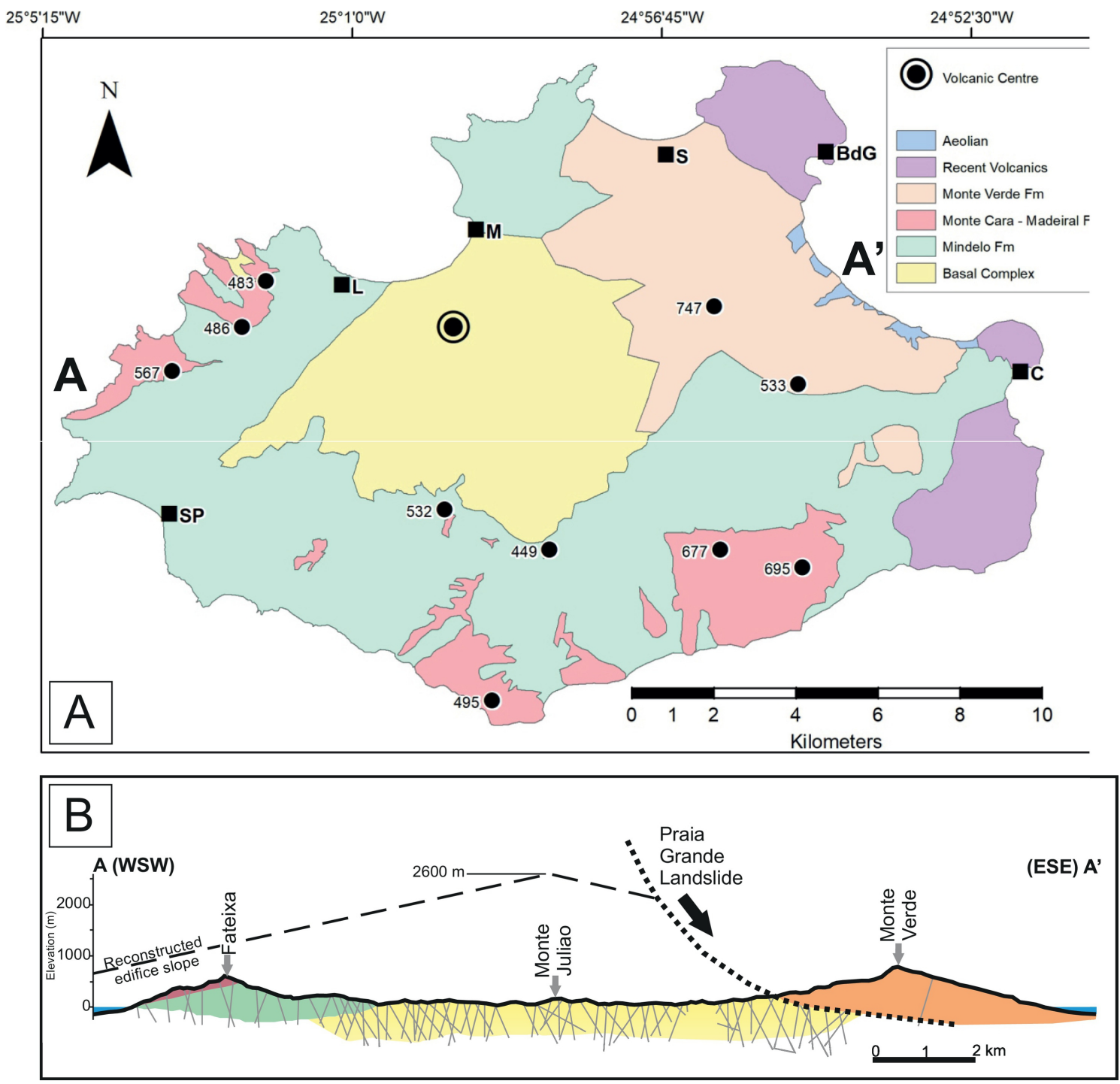

Figure 3 


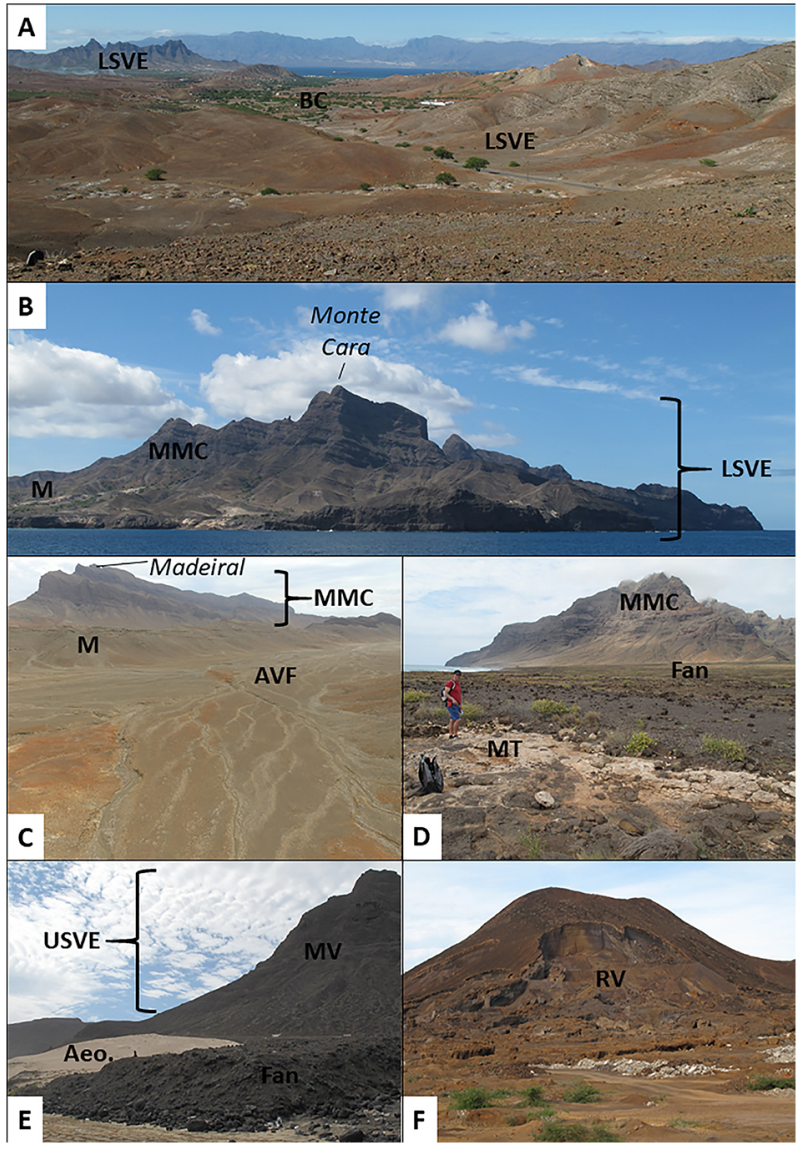

Figure 4 


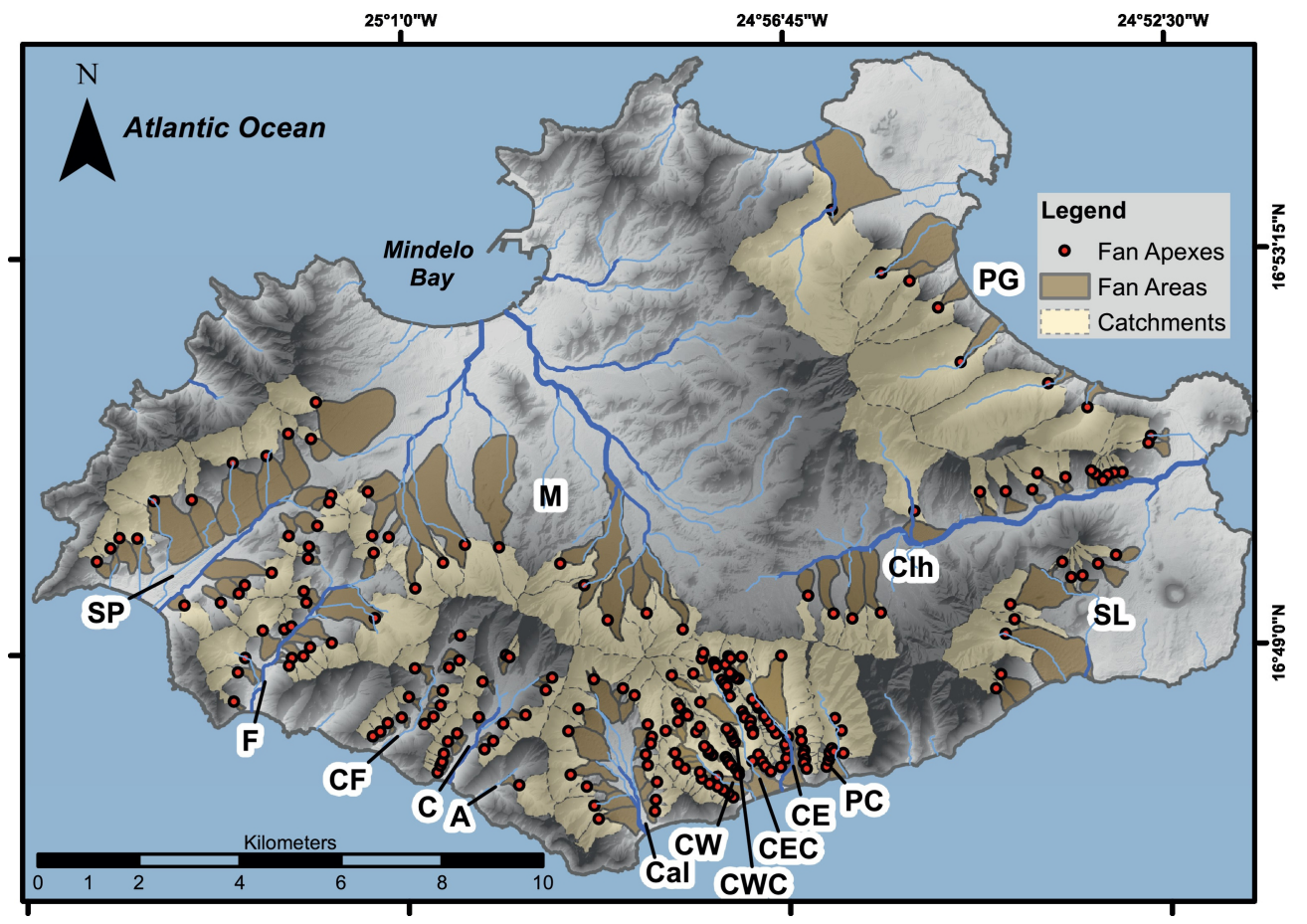

Figure 5 


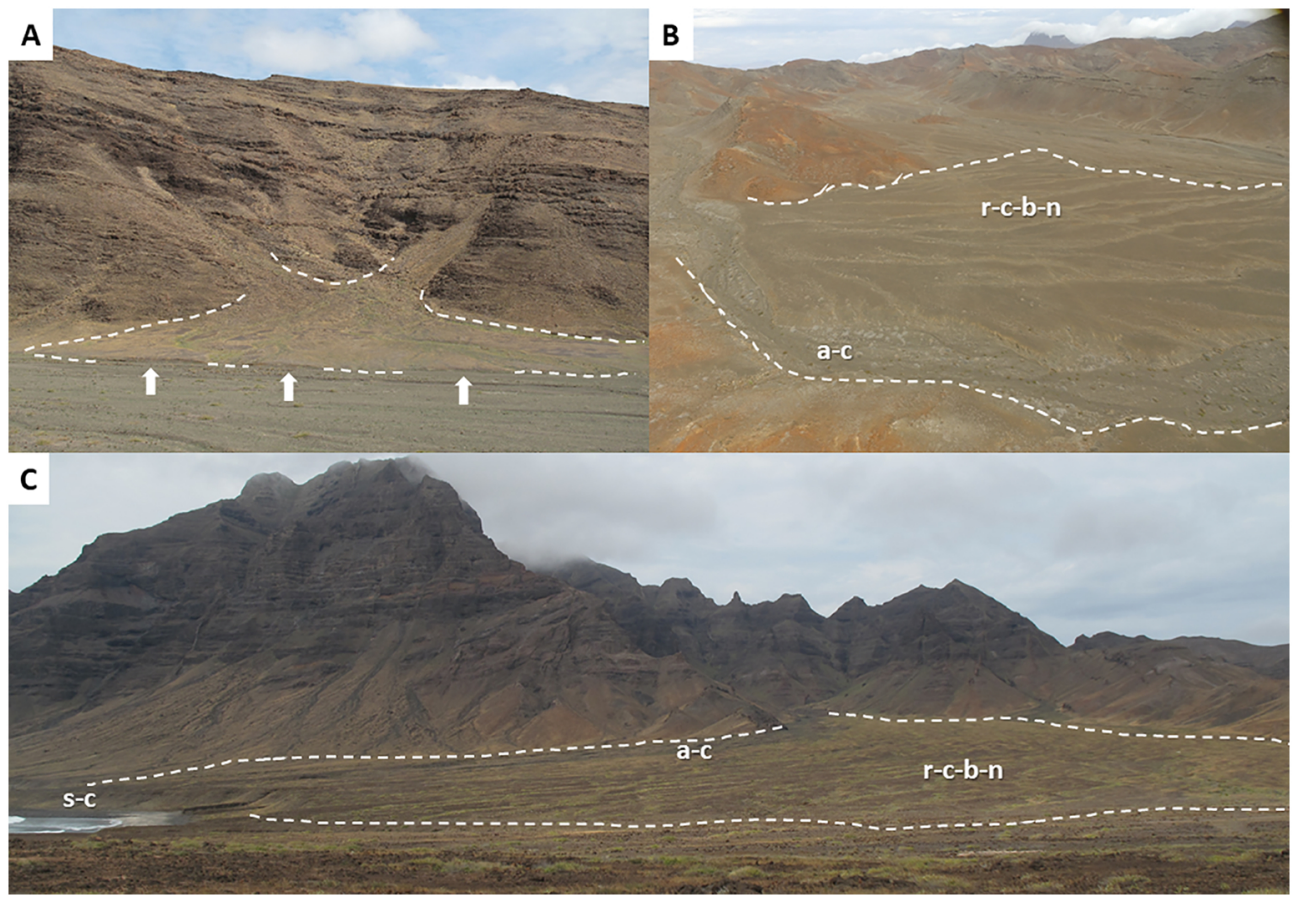

Figure 6 


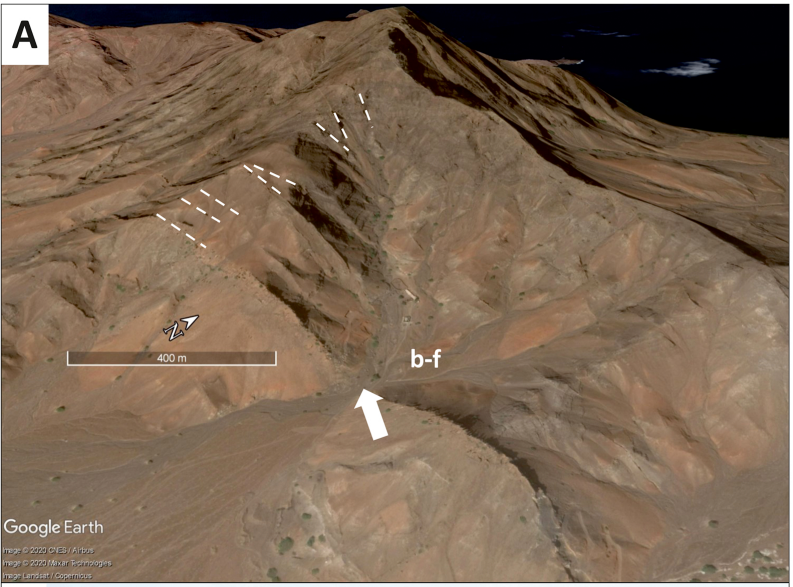

\section{B}
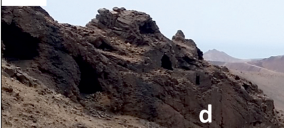

$d d^{d}+d^{d} d$

a

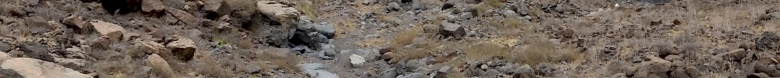

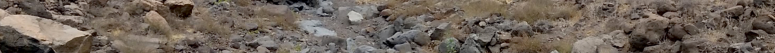

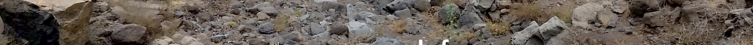

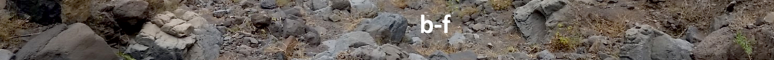
Ans (4)

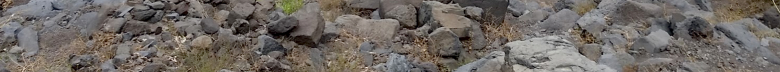

Figure 7 


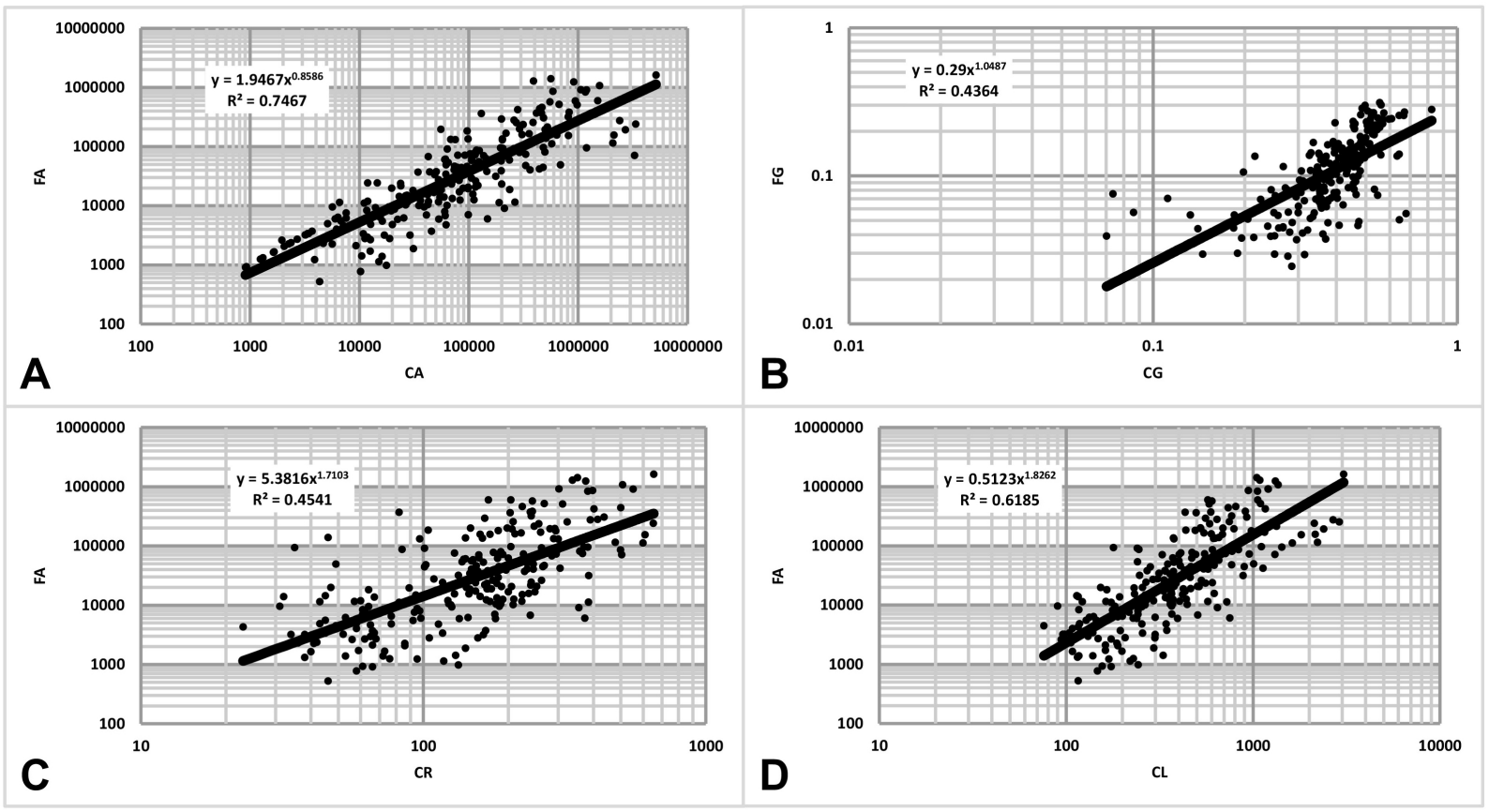

Figure 8 


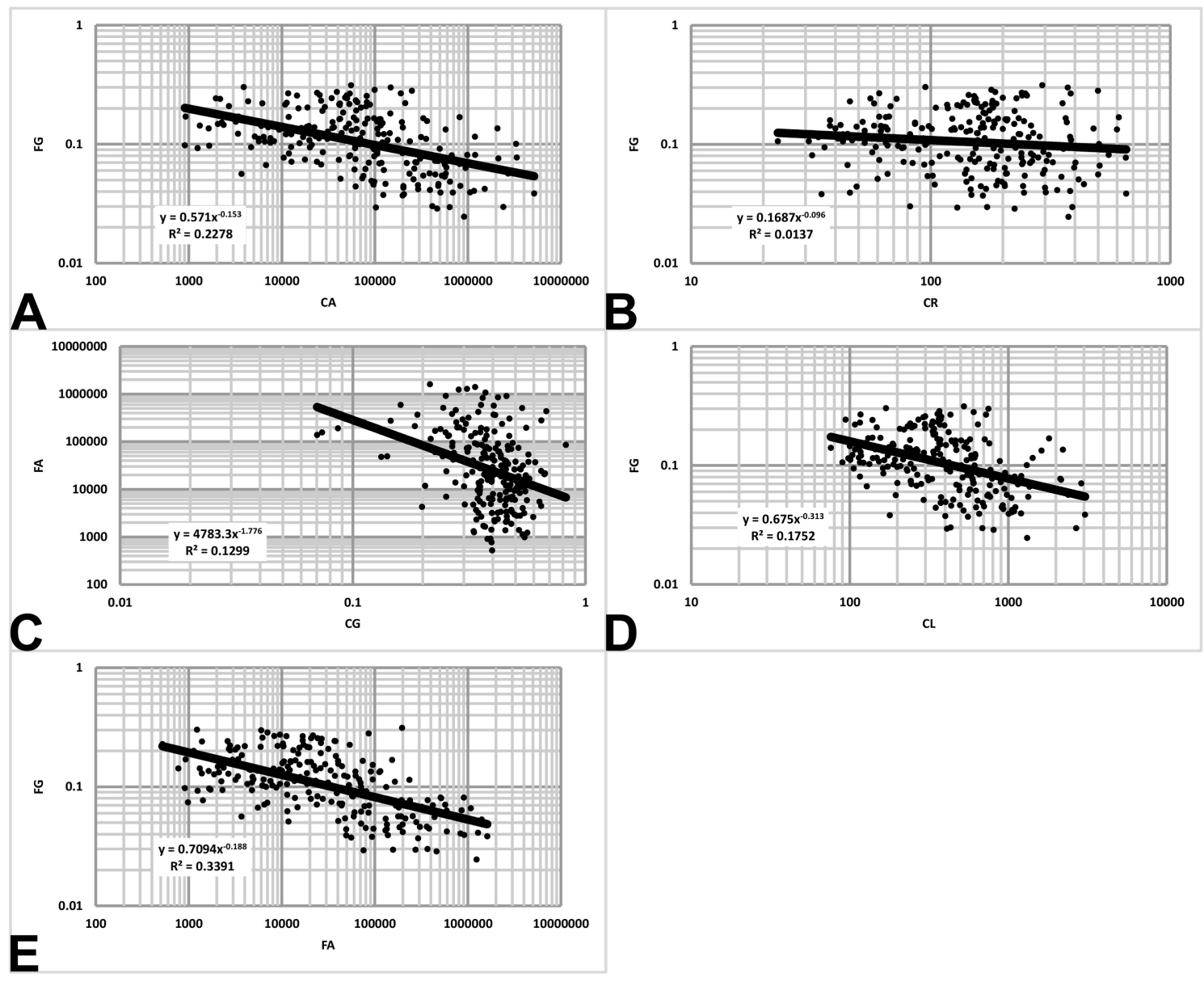

Figure 9 


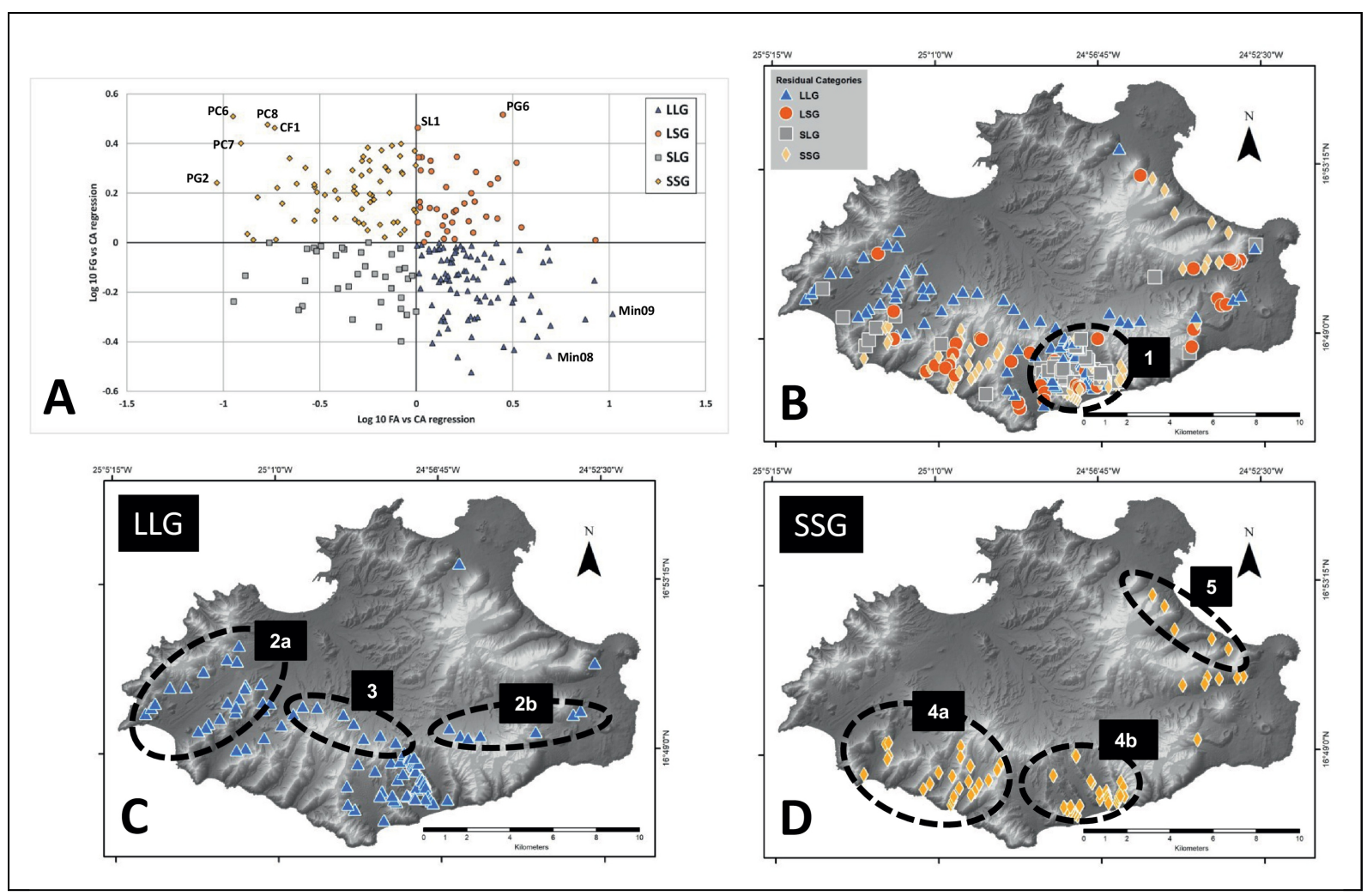

Figure 10 
A)
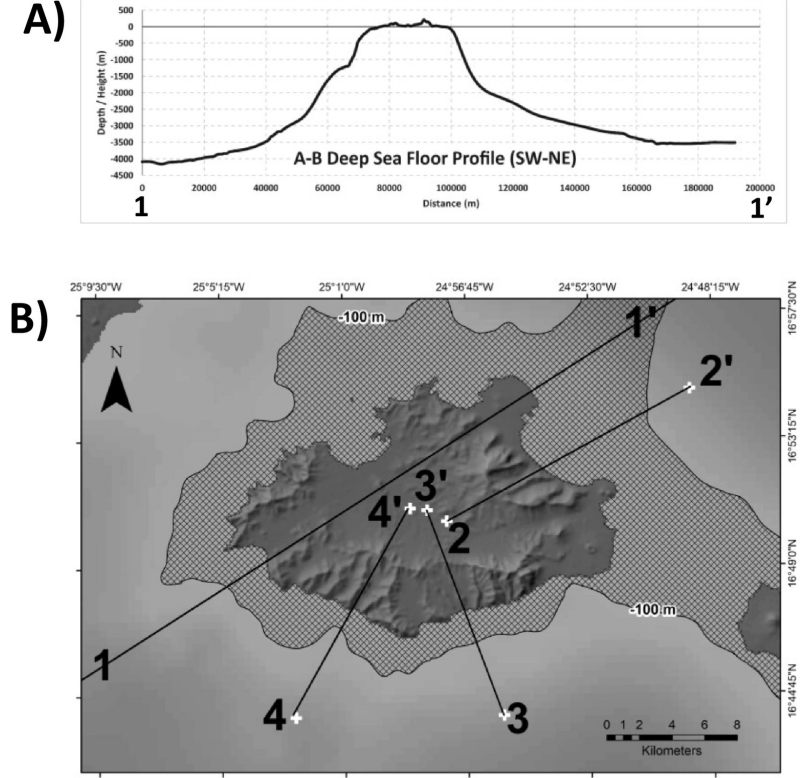

C)
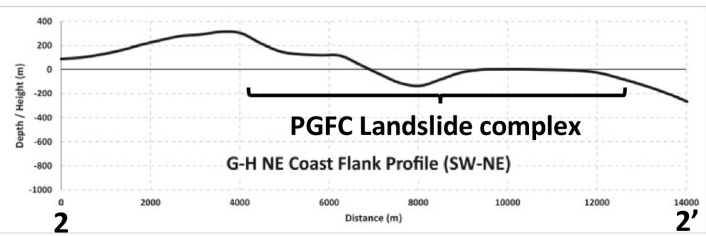

D)

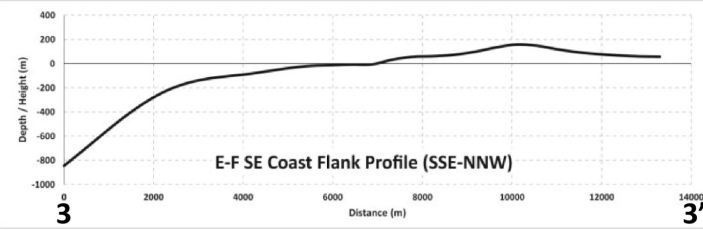

E)

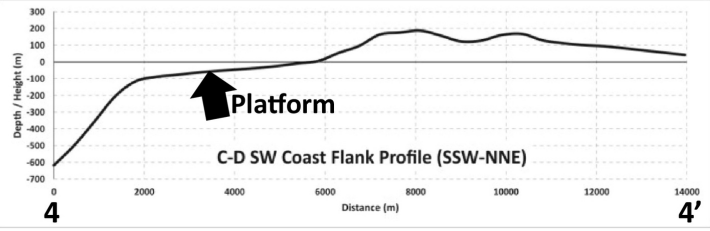



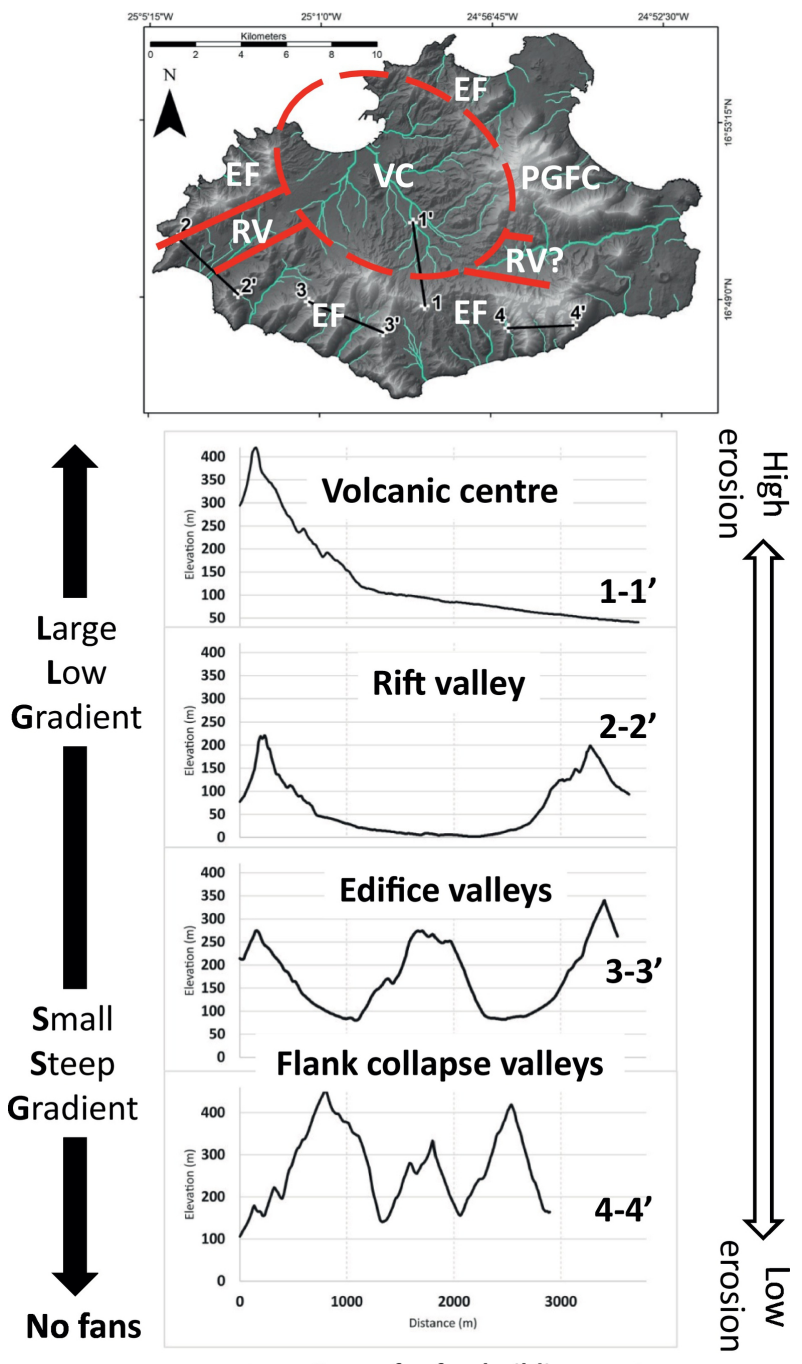

Space for fan building

Figure 12 